\title{
Asymmetric biocatalytic synthesis of fluorinated pyridines through transesterification or transamination. Computational insights into the reactivity of transaminases.
}

\author{
María López-Iglesias, ${ }^{\text {a,b }}$ Daniel González-Martínez, ${ }^{\mathrm{a}}$ María Rodríguez-Mata, ${ }^{\mathrm{a}}$ Vicente \\ Gotor, ${ }^{\mathrm{a}}$ Eduardo Busto, ${ }^{\mathrm{c}, *}$ Wolfgang Kroutil ${ }^{\mathrm{b}, *}$ and Vicente Gotor-Fernández ${ }^{\mathrm{a}, *}$
}

\footnotetext{
a Departamento de Química Orgánica e Inorgánica, Instituto Universitario de Biotecnología de Asturias, Universidad de Oviedo, 33006 Oviedo, Spain. Telephone: +34985103454; Fax number: +34985103446. E-mail: vicgotfer@uniovi.es b Department of Chemistry, Organic and Bioorganic Chemistry, University of Graz, NAWI Graz, BioTechMed Graz, Heinrichstraße 28, 8010 Graz, Austria. Telephone: +433163805350; Fax number: +433163809840. E-mail: wolfgang.kroutil@uni-graz.at.

c Departamento de Química Orgánica I, Facultad de Química, Universidad Complutense de Madrid, 28040 Madrid, Spain. Telephone: +34913944231; Fax number: +34913944103. E-mail: bbusto@ucm.es
}

Received: ((will be filled in by the editorial staff))

Supporting information for this article is available on the WWW under http://dx.doi.org/10.1002/adsc.201\#\#\#\#\#.

\begin{abstract}
The synthesis of a family of pyridines bearing a fluorinated substituent on the aromatic ring has been carried out through two independent and highly stereoselective chemoenzymatic strategies. Short chemical synthetic routes toward fluorinated racemic amines and prochiral ketones have been developed, which served as substrates to explore the suitability of lipases and transaminases in asymmetric biotransformations. The lipase-catalyzed kinetic resolution via acylation of racemic amines proceeded smoothly giving conversions close to $50 \%$ and excellent enantioselectivities. Alternatively, the biotransamination of the corresponding prochiral ketones was investigated giving access to both optically pure amine enantiomers using transaminases with
\end{abstract}

\section{Introduction}

The synthesis of organofluorine compounds has received great attention in recent years due to their uses in different scientific areas. ${ }^{[1]}$ Fluorinated organic molecules possess a wide range of applications as agrochemicals, ${ }^{[2]}$ pharmaceuticals, ${ }^{[3]}$ and asymmetric catalysts. ${ }^{[4]}$ In a rough estimation, around $20 \%$ pharmaceuticals and $40 \%$ agrochemicals contain at least one fluorine atom in their structure. ${ }^{[5]}$ The incorporation of fluorine in organic molecules may lead to important changes in their stability, bioavailability and binding affinity to receptors. ${ }^{[6]}$ The fluorine presence can significantly affect their physicochemical properties such as acidity, hydrogen-bonding, lipophilicity, solubility and biological properties, ${ }^{[7]}$ improving metabolic stability and making possible the discovery of new drug candidates. ${ }^{[8]}$ In this context, the development of heterocyclic systems bearing fluorinated functionalities opens up the access to new valuable molecules. ${ }^{[9]}$

Biocatalytic methodologies have been described for the production of biologically active organofluorine molecules through selective complementary selectivity. High to quantitative conversion values were achieved, which allowed the isolation of the amines in moderate to high yields (40$88 \%)$.

A deeper understanding of the latter process was enabled by performing theoretical calculations on thermodynamic and mechanistic aspects. Calculations showed that the biotransamination reactions are highly favoured by the presence of fluorine atoms and the pyridine ring.

Keywords: Amines; Asymmetric synthesis; Biocatalysis; Computational chemistry; Organofluorinated compounds; Pyridines

halogenation using halogenases. ${ }^{[10]}$ Alternatively, the asymmetrization of prochiral or racemic starting materials allows the access to enantiopure fluorinated compounds by using other classes of enzymes such as alcohol dehydrogenases, ${ }^{[11]}$ hydrolases ${ }^{[12]}$ or transaminases. ${ }^{[13]}$

Chiral amines are interesting and versatile compounds with great appeal in both academic and industrial fields. ${ }^{[14]}$ This structural motif is nowadays considered as an interesting scaffold in the preparation of bioactive molecules. ${ }^{[15]}$ In this context, the development of stereoselective biocatalytic methods toward optically active amines has attracted increasing attention in recent years. ${ }^{[16]}$ The present work combines the relevance that chiral amines offer and the potential of compounds bearing fluorine atoms, as both are challenging items for the scientific community. Hence, a series of pyridylethanamine enantiomers containing a fluorine atom or a trifluoromethyl group at the 5- or 6-position of the heteroaromatic ring have been stereoselectively synthesized by two independent enzymatic approaches: (a) lipase-catalyzed kinetic resolution via transesterification or (b) highly efficient asymmetric amination employing transaminases. 


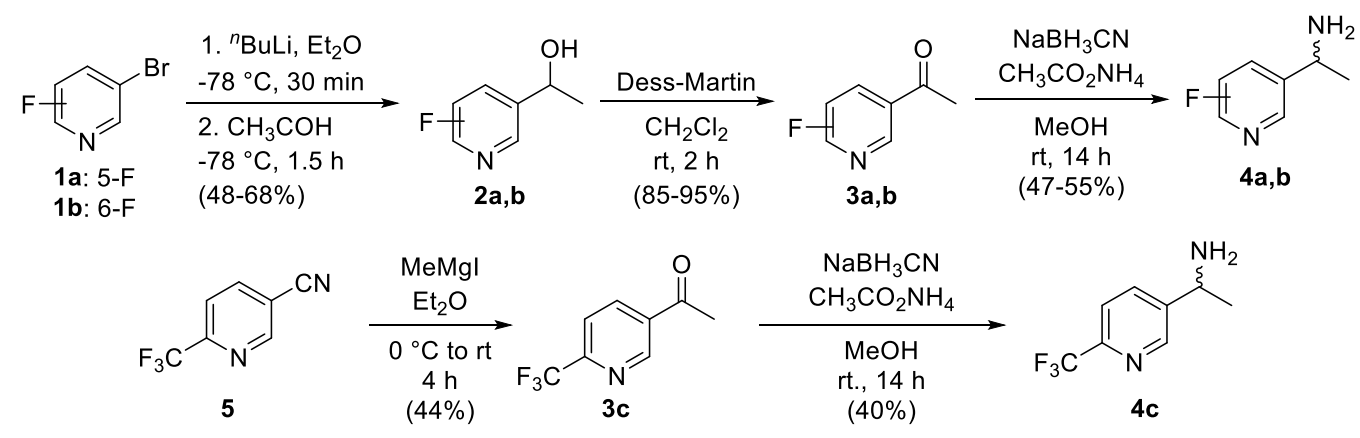

Scheme 1. Synthesis of ketones 3a-c and racemic amines 4a-c for the study of its enzymatic amination or kinetic resolution, respectively.

\section{Results and Discussion}

The synthetic pathway has been chosen in accordance with the availability of the commercial substrates as well as the viability of the chemical process. Racemic amines $\mathbf{4 a}$ and $\mathbf{4 b}$ bearing fluorine atoms at 5- or 6position of the pyridine ring were synthesized in moderate yields via a two-step hydroxyalkylation of the corresponding 5-bromopyridines $\mathbf{1 a}$ and $\mathbf{1 b}$, respectively (Scheme 1, top). A subsequent chemical oxidation of the resulting racemic alcohols $\mathbf{2 a}$ and $\mathbf{2 b}$ using the Dess-Martin reagent in dichloromethane allowed the isolation of the ketones $\mathbf{3 a}$ and $\mathbf{3 b}(85-$ $95 \%$ isolated yield). Then, these ketones were submitted to a classical reductive amination employing sodium cyanoborohydride and ammonium acetate in methanol. In the particular case of the trifluoromethylated derivative $\mathbf{4 c}$, the alternative pathway compromises only two steps: first, addition of methylmagnesium iodide to the cyano group of the commercially available 6(trifluoromethyl)nicotinonitrile (5) and, secondly, the reductive amination of the so-obtained ketone 3c (Scheme 1, bottom). These methodologies for racemic amine syntheses are useful for further application in enzymatic reactions. On the one hand, the three racemates will serve as both substrates for lipase-catalyzed transformations and final products for analytical purposes in biotransamination experiments. On the other hand, the intermediate ketones will be the substrates in transaminasecatalyzed reactions.

Once completed the synthesis of the ketones 3a-c and amines 4a-c, two stereoselective enzymatic strategies were studied: the classical kinetic resolution through lipase-catalyzed enantioselective acylation of the racemic amines 4a-c and, alternatively, the amination of prochiral ketones 3a-c using transaminases.

\section{Asymmetric synthesis through lipase-catalyzed resolutions}

The potential of lipases in the acylation of racemic amines has been broadly studied as an efficient strategy for the synthesis of enantiopure amines in organic solvents under mild reaction conditions. ${ }^{[16 c, 17]}$ On this basis, the classical kinetic resolution of the fluorinated 1-(pyridin-3-yl)ethanamines 4a-c was attempted. The initial reaction conditions were rationally established according to the following remarks. First of all, Candida antarctica lipase B (CAL-B, Novozyme 435) was selected as suitable biocatalyst due to the good results reported in literature on structurally similar substrates. ${ }^{[18]}$ Ethyl methoxyacetate was chosen as acylating agent due to the excellent selectivity and activity values displayed in the resolution of racemic amines. ${ }^{[19]}$ THF was preferred as solvent owing to solubility issues, using a $100 \mathrm{mM}$ substrate concentration for the study (Table 1).

Table 1. CAL-B-catalyzed kinetic resolution of racemic amines 4a-c through enantioselective acylation. ${ }^{[a]}$

\begin{tabular}{|c|c|c|c|c|c|c|}
\hline Entry & $4 a-c$ & $\begin{array}{l}t \\
\text { (h) }\end{array}$ & $\begin{array}{l}e e_{\mathrm{S}} \\
(\%)^{[\mathrm{b}]}\end{array}$ & $\begin{array}{l}e e_{\mathrm{P}} \\
(\%)^{[\mathrm{b}]}\end{array}$ & $\begin{array}{l}c \\
(\%)^{[\mathrm{c}]}\end{array}$ & $E^{[\mathrm{d}]}$ \\
\hline 1 & a (5-F) & 7 & 90 & $>99$ & 47 & $>200$ \\
\hline 2 & b (6-F) & 2 & 96 & & & $>200$ \\
\hline 3 & c $\left(6-\mathrm{CF}_{3}\right)$ & 3 & 94 & $>99$ & 49 & $>200$ \\
\hline \multicolumn{7}{|c|}{$\begin{array}{l}\text { [a] Reaction conditions: racemic amine } 4 \mathrm{a}-\mathrm{c}(100 \mathrm{mM}) \text { in } \\
\text { THF, ethyl methoxyacetate }(5 \text { equiv) and a ratio of } \\
\text { substrate: CAL-B } 1: 1(\mathrm{w} / \mathrm{w}) \text { at } 30^{\circ} \mathrm{C} \text { and } 250 \mathrm{rpm} \text {. } \\
\text { [b] Determined by HPLC on a chiral column by analysing } \\
\text { the methoxyacetamides or the corresponding acetamides } \\
\text { obtained after derivatization of the enantioenriched amines } \\
\text { (see Supporting Information). } \\
\text { [c] } c=e e_{s} /\left(e e_{s}+e e_{p}\right) \text {. } \\
{ }^{[\mathrm{d}]} E=\ln \left[(1-c)\left(1-e e_{p}\right)\right] / \ln \left[(1-c)\left(1+e e_{p}\right)\right] \cdot{ }^{[20]}\end{array}$} \\
\hline
\end{tabular}

Enzymatic reactions took place with excellent enantioselectivity for all the three tested substrates, and conversions reached almost the maximum 50\% value in short reaction times $(2-7 \mathrm{~h}$, Table 1 , entries 1-3). Thus, this methodology afforded the enantiopure methoxyacetamides $(R)$-6a-c and the remaining amines $(S)-\mathbf{4 a - c}$ in up to $96 \% e e$. Control experiments were performed revealing that CAL-B was undoubtedly responsible of the catalysis. Amide formation was not detected in the absence of enzyme, 
which was expected based on the excellent selectivities observed in all cases.

\section{Asymmetric synthesis through biotransamination}

In the pursuit of enzymatic strategies that led to theoretically $100 \%$ yield processes toward optically active amines, transaminases (TAs) were chosen as alternative biocatalysts. ${ }^{[16 b, 21]}$ This option allowed to take advantage of the synthetic pathway previously described, as the ketones 3a-c, which are now substrates for transamination experiments, were indeed prepared as intermediates in the synthesis of the amines 4a-c studied in lipase-catalyzed acylations. Thus, a number of representative transaminases overexpressed in E. coli were considered, working at a $50 \mathrm{mM}$ substrate concentration (Table 2). These transaminases are the $(S)$-selective from Vibrio fluvialis, $^{[22]}$ Chromobacterium violaceum $^{[23]}$ and Arthrobacter citreus, ${ }^{[24]}$ and the $(R)$-selective from Arthrobacter sp. ${ }^{[25]}$ and its evolved variant called ArRmut11 ${ }^{[26]}$ used as semipurified form by a heat treatment (see Experimental section).

According to the biocatalyst tolerance, alanine (system a) or an excess of 2-propylamine (1 M, system b) were selected as amino source, including in the first case a pyruvate removal system formed by $\mathrm{NAD}^{+} /$ammonium formate/alanine dehydrogenase $(\mathrm{AlaDH}) /$ formate dehydrogenase $(\mathrm{FDH})$ working in parallel with the main reaction. Despite the important differences detected in reactivity depending on both the transaminase and the substrate, it is noteworthy the excellent enantioselectivity obtained in all cases for the production of amines $\mathbf{4 a - c}$ (>99\% ee).

Table 2. Asymmetric biotransamination of ketones 3a-c using different amino sources. ${ }^{[a]}$

(a)

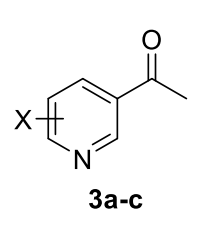

$\mathrm{H}_{2} \mathrm{O}+\mathrm{CO}_{2}$

TA, PLP

buffer $\mathrm{KPi}$ pH 7 $30^{\circ} \mathrm{C}, 24 \mathrm{~h}, 120 \mathrm{rpm}$

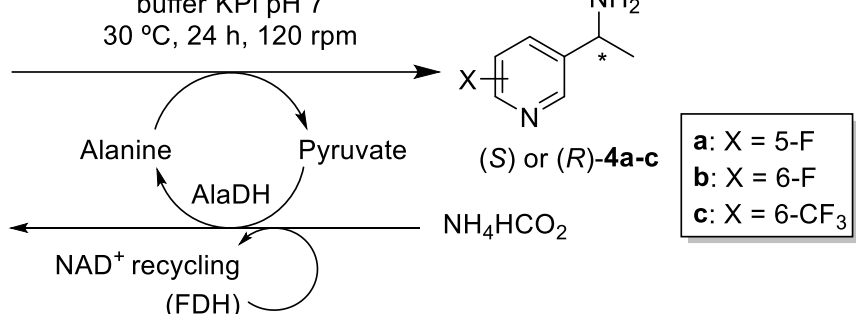

(b)

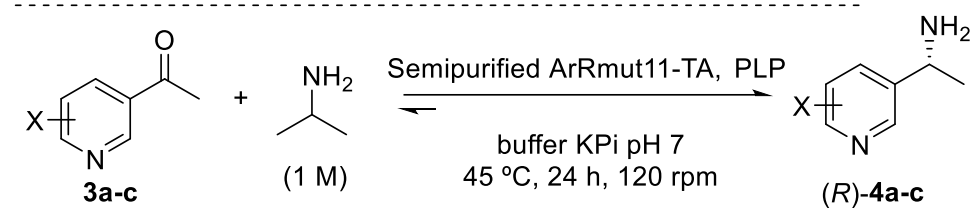

\begin{tabular}{|c|c|c|c|c|c|}
\hline Entry & 3a-c & TA & System & $c(\%)^{[\mathrm{b}]}$ & $e e_{\mathrm{P}}(\%)^{[\mathrm{c}]}$ \\
\hline 1 & a (5-F) & Vibrio fluvialis & (a) & 89 & $>99(S)$ \\
\hline 2 & $\mathbf{a}(5-\mathrm{F})$ & Chromobacterium violaceum & (a) & 80 & $>99(S)$ \\
\hline 3 & $\mathbf{a}(5-\mathrm{F})$ & Arthrobacter citreus & (a) & 36 & $>99(S)$ \\
\hline 4 & $\mathbf{a}(5-\mathrm{F})$ & Arthrobacter sp. & (a) & 85 & $>99(R)$ \\
\hline 5 & $\mathbf{a}(5-\mathrm{F})$ & Semipurified ArRmut11 & (b) & 69 & $>99(R)$ \\
\hline 6 & b $(6-F)$ & Vibrio fluvialis & (a) & 26 & $>99(S)$ \\
\hline 7 & b (6-F) & Chromobacterium violaceum & (a) & 45 & $>99(S)$ \\
\hline 8 & b (6-F) & Arthrobacter citreus & (a) & $<1$ & n.m. \\
\hline 9 & b (6-F) & Arthrobacter sp. & (a) & 75 & $>99(R)$ \\
\hline 10 & b (6-F) & Semipurified ArRmut11 & (b) & 6 & n.m. \\
\hline 11 & c $\left(6-\mathrm{CF}_{3}\right)$ & Vibrio fluvialis & (a) & 69 & $>99(S)$ \\
\hline 12 & c $\left(6-\mathrm{CF}_{3}\right)$ & Chromobacterium violaceum & (a) & 80 & $>99(S)$ \\
\hline 13 & c $\left(6-\mathrm{CF}_{3}\right)$ & Arthrobacter citreus & (a) & 36 & $>99(S)$ \\
\hline 14 & c $\left(6-\mathrm{CF}_{3}\right)$ & Arthrobacter sp. & (a) & 94 & $>99(R)$ \\
\hline 15 & c $\left(6-\mathrm{CF}_{3}\right)$ & Semipurified ArRmut11 & (b) & 85 & $>99(R)$ \\
\hline
\end{tabular}

${ }^{[a]}$ Reaction conditions in system a: phosphate buffer $(100 \mathrm{mM}, \mathrm{pH}$ 7), ketone 3a-c $(50 \mathrm{mM})$, lyophilized cells $E$. coli/TA $(20 \mathrm{mg}), \mathrm{PLP}(1 \mathrm{mM}), \mathrm{NAD}^{+}(1 \mathrm{mM}), \mathrm{L}-$ or D-alanine $(250 \mathrm{mM})$, AlaDH $(10 \mu \mathrm{L}, 11 \mathrm{U})$, FDH (2.6 mg, $\left.11 \mathrm{U}\right)$, ammonium formate $(150 \mathrm{mM}), 24 \mathrm{~h}$ at $30^{\circ} \mathrm{C}$ and $120 \mathrm{rpm}$. Reaction conditions in system b: phosphate buffer $(100 \mathrm{mM}, \mathrm{pH} 7)$, ketone 3a-c $(50 \mathrm{mM})$, semipurified ArRmut11-TA $(500 \mu \mathrm{L})$, PLP $(0.5 \mathrm{mM})$, 2-propylamine $(1 \mathrm{M}), 24 \mathrm{~h}$ at $45^{\circ} \mathrm{C}$ and $120 \mathrm{rpm}$.

${ }^{[b]}$ Conversion values were determined by $\mathrm{GC}$ analysis after isolation of products by extraction from basified media (see Experimental section).

${ }^{[c]}$ Enantiomeric excess values were measured by GC on a chiral column after the in situ derivatization with acetic anhydride of the resulting amines (see Supporting Information). n.m.: not measured. 
Table 3. Asymmetric biotransamination of ketones 3a-c using alanine dehydrogenase system and performing a rehydration step of the TA before its use in the enzymatic reaction. ${ }^{\mathrm{a}}$

\begin{tabular}{lllll}
\hline Entry & 3a-c & TA & $c(\%)^{[\mathrm{b}]}$ & $e e_{\mathrm{P}}(\%)^{[\mathrm{c}]}$ \\
\hline 1 & $\mathbf{a}(5-\mathrm{F})$ & Vibrio fluvialis & 90 & $>99(S)$ \\
2 & $\mathbf{a}(5-\mathrm{F})$ & Chromobacterium violaceum & $99(71)$ & $>99(S)$ \\
3 & $\mathbf{a}(5-\mathrm{F})$ & Arthrobacter $\mathrm{sp}$. & $99(79)$ & $>99(R)$ \\
\hline 4 & $\mathbf{b}(6-\mathrm{F})$ & Chromobacterium violaceum & $88(40)^{\mathrm{d}}$ & $>99(S)$ \\
5 & $\mathbf{b}(6-\mathrm{F})$ & Arthrobacter $\mathrm{sp}$. & 92 & $>99(R)$ \\
\hline 6 & $\mathbf{c}\left(6-\mathrm{CF}_{3}\right)$ & Chromobacterium violaceum & $>99$ & $>99(S)$ \\
7 & $\mathbf{c}\left(6-\mathrm{CF}_{3}\right)$ & Arthrobacter sp. & $>99(88)$ & $>99(R)$ \\
\hline
\end{tabular}

${ }^{[a]}$ Reaction conditions: lyophilized cells $E$. coli/TA $(20 \mathrm{mg})$ rehydrated in phosphate buffer $(100 \mathrm{mM}, \mathrm{pH} \mathrm{7)} \mathrm{for} 30 \mathrm{~min}$ at $30{ }^{\circ} \mathrm{C}$ and $120 \mathrm{rpm}$, ketone 3a-c $(50 \mathrm{mM})$, PLP $(1 \mathrm{mM}), \mathrm{NAD}^{+}(1 \mathrm{mM})$, L- or D-alanine $(250 \mathrm{mM}), \mathrm{AlaDH}(10 \mu \mathrm{L}, 11 \mathrm{U})$, FDH $(2.6 \mathrm{mg}, 11 \mathrm{U})$, ammonium formate $(150 \mathrm{mM}), 24 \mathrm{~h}$ at $30^{\circ} \mathrm{C}$ and $120 \mathrm{rpm}$.

[b] Conversion values were determined by GC analysis after isolation of products by extraction in basified media (see Experimental section). Isolated yields in parentheses.

[c] Enantiomeric excess values were measured by GC on a chiral column after an in situ derivatization with acetic anhydride of the resulting amines (see Supporting Information).

[d] A further purification step by column chromatography was performed in order to separate the product from the unreacted ketone.

Starting with ketone 3a, good conversion values were observed in the formation of the amine $(S)-\mathbf{4 a}$ with the TAs from Vibrio fluvialis and Chromobacterium violaceum (Table 2, entries 1 and $2)$, while the TA from Arthrobacter citreus only led to a $36 \%$ conversion (Table 2 , entry 3 ). For the $(R)-$ selective enzymes a $85 \%$ conversion was obtained with the TA from Arthrobacter sp. (Table 2, entry 4), and $69 \%$ with the system $b$ and the mutant ArRmut11-TA (Table 2, entry 5). In all cases, the amine 4a was isolated in enantiopure form.

When ketone $\mathbf{3 b}$ bearing a fluorine atom substituting 6-position of the aromatic ring was subjected to enzymatic transamination, a significant decrease in reactivity was noticed (Table 2, entries 610). The TA from Chromobacterium violaceum is linked to the best results within the $(S)$-selective enzymes (Table 2, entry 7), achieving low to moderate conversion values in all the cases (Table 2, entries 6-8), whereas for the $(R)$-selective TAs (Table 2, entries 9 and 10) the Arthrobacter sp. allowed the formation of the enantiopure amine $(R)-\mathbf{4 b}$ with a notable $75 \%$ conversion (Table 2, entry 9). Remarkably, the more hindered 6-trifluoromethylated pyridine 3c showed an enhanced reactivity displaying a similar trend as that observed for substrate 3a. Thus, excellent conversions were achieved with the $(R)$ Arthrobacter leading to the amine $(R)-\mathbf{4 c}$ in enantiopure form (94\%, Table 2, entry 14), and the Chromobacterium violaceum TA allowed the formation of the counterpart $(S)-\mathbf{4} \mathbf{c}$ in a good extent (80\%, Table 2, entry 12$)$.

These promising results led us to make some adjustments in the reaction conditions in the belief that an improvement in conversions could be achieved by increasing the substrate solubility, a parameter identified as key factor of the process. However, the presence of water-miscible organic cosolvents did not cause significant improvement on the amine formation (Table S1), and even lower conversions were observed when alanine was used as amine donor (Table S2). A similar behaviour was found when the amount of enzyme was doubled, even when the presence of too many immiscible solids in the reaction medium was avoided by employing cell free extract enzymes obtained after breaking cell walls by sonication cycles of the enzymatic crude (Table S3).

Having obtained some good results but not fully satisfactory ones, we decided to alter the enzyme performance by introducing an initial enzyme rehydration step. Therefore, the TA and the buffer were shaken at $30{ }^{\circ} \mathrm{C}$ and $120 \mathrm{rpm}$ for $30 \mathrm{~min}$ prior to their use in the biotransamination experiments (Table 3 ). We were pleased to see a significant improvement of conversion values, some of the substrates displaying even $99 \%$ conversions as for $\mathbf{3 a}$ and $\mathbf{3 c}$ using both $(S)$ - and $(R)$-selective transaminases (Table 3, entries 2 and 3 for 3a, 6 and 7 for 3c). This rehydration step enhanced the reactivity for the fluorine-substituted ketone $\mathbf{3 b}$ as well (Table 3, entries 4 and 5), keeping intact the exquisite enantioselectivity in all cases.

With the best results in hand, preparative scale biotransformations were performed employing these optimized conditions. When TAs from Chromobacterium violaceum and Arthrobacter sp. were employed, enantiopure amine $(S)-\mathbf{4 a}$ as well as the antipode $(R)-\mathbf{4 a}$ were successfully isolated in good yields $(71 \%$ and $79 \%$, respectively, entries 2 and 3) just by performing a basic extraction after completion of the reaction. Similarly, the Arthrobacter sp. TA provided the amine $(R)-\mathbf{4 c}$ in enantiopure form and very high isolated yield (88\%, entry 7). While the ${ }^{1} \mathrm{H}-\mathrm{NMR}$ analysis of the crude reaction mixture revealed high purity for amines $(S)$ $\mathbf{4 a},(R)-\mathbf{4 a}$ and $(R)-\mathbf{4 c}$, the biotransamination reaction of ketone $\mathbf{3 b}$ with Chromobacterium violaceum TA did not proceed to completion, so a column chromatography purification was necessary to separate the unreacted ketone $\mathbf{3 b}$ from the enantiopure amine $(S)-4 b$. In the latest case only a $40 \%$ yield was obtained.

Next, absolute configurations were assigned through circular dichroism (CD) spectroscopy analyses. A structurally related compound to the 
family of pyridines studied here, 1-(pyridin-3yl)ethan-1-amine (4d), whose optical rotation values are already reported in literature ${ }^{[27]}$ was chosen as reference. Firstly, optically active $(S)$ - and $(R)-\mathbf{4 d}$ were isolated by carrying out a 50-mg scale up of the enzymatic transamination employing the Chromobacterium violaceum and Arthrobacter sp. TAs, respectively. Then, CD experiments were performed observing a negative minimum at 265.6 $\mathrm{nm}$ for $(S)-\mathbf{4 d}$ and a positive maximum for its counterpart $(R)-\mathbf{4 d}$ at $264.2 \mathrm{~nm}$ (Figure 1, left). Qualitative comparison of the CD spectra measured for both enantiomers of reference pyridine $4 \mathbf{d}$ with the corresponding spectra of the unknown pyridines 4a-c (Figure 1, right) allowed us to confirm their absolute configuration, which is in agreement either with the transaminases expected selectivity and the Kazlauskas' rule ${ }^{[28]}$ for the optically active amines obtained through lipase-catalyzed reactions.

At this point all the amines 4a-c have been isolated with excellent enantiomeric excess, but still no quantitative transformations have been developed for all the substrates, something that is significant enough to cause a decrease in the isolated yield of the 6-F-substituted amine $\mathbf{4 b}$. For that reason, we decided to deeper investigate the biotransamination of 3a-c based on computational calculations. The thermochemical study highlights substantial differences in the thermodynamic stabilization of the fluorinated pyridines, which are reflected in the calculated $\Delta G$ of the amination reaction for the different ketone/amine pairs at the M06-2X/6$311++\mathrm{G}(3 \mathrm{df}, 2 \mathrm{p})$ level (Scheme 2, top). The values revealed that the global equilibrium using isopropylamine as amine donor is shifted toward the amine formation for $\mathbf{4 a}$ and $\mathbf{4 c}$ derivatives, while for pyridine 4b this was found to be unfavourable (see additional information in Table S8). Interestingly, a relative energy difference of $7.5 \mathrm{~kJ} / \mathrm{mol}$ was found between 5-F and 6-F substituted pyridines ( $\mathbf{3 a}$ and $\mathbf{3 b}$, respectively) in the transamination reaction.

Furthermore, the thermodynamic study was extended for the structurally analogues acetophenones 3e-g (Scheme 2, bottom), the amine formation being in all cases less favourable in comparison with the corresponding pyridine pairs $\mathbf{3 a}$ c. The influence of the nitrogen atom was experimentally confirmed in the biotransamination of 3g employing both 2-isopropylamine and alanine as amine donors, which led to moderate conversions that are far from the values obtained for the corresponding pyridine 3c (Tables S4 and S5, respectively). We have recently reported a similar tendency of stabilization by the pyridine ring in comparison with benzene derivatives, in this case due to the formation of an intramolecular hydrogen bond. ${ }^{[29]}$

In our interest in having a deep knowledge of the process, key intermediates of the known reaction mechanism in the Chromobacterium violaceum TA active site were also analyzed through different computational approaches (Figures S2 and S3). ${ }^{[30]}$ The ketimine and aldimine intermediates were selected for the study of each substrate, which is covalently bonded to the PLP cofactor (Figure 2, left).

Initially, docking experiments were performed using the AutoDock software (Figures S4, see Supporting Information for details) ${ }^{[31]}$ finding in the most stable conformations of the intermediates the pyridoxal ring located at the crystallographic position (Figure 2, right).

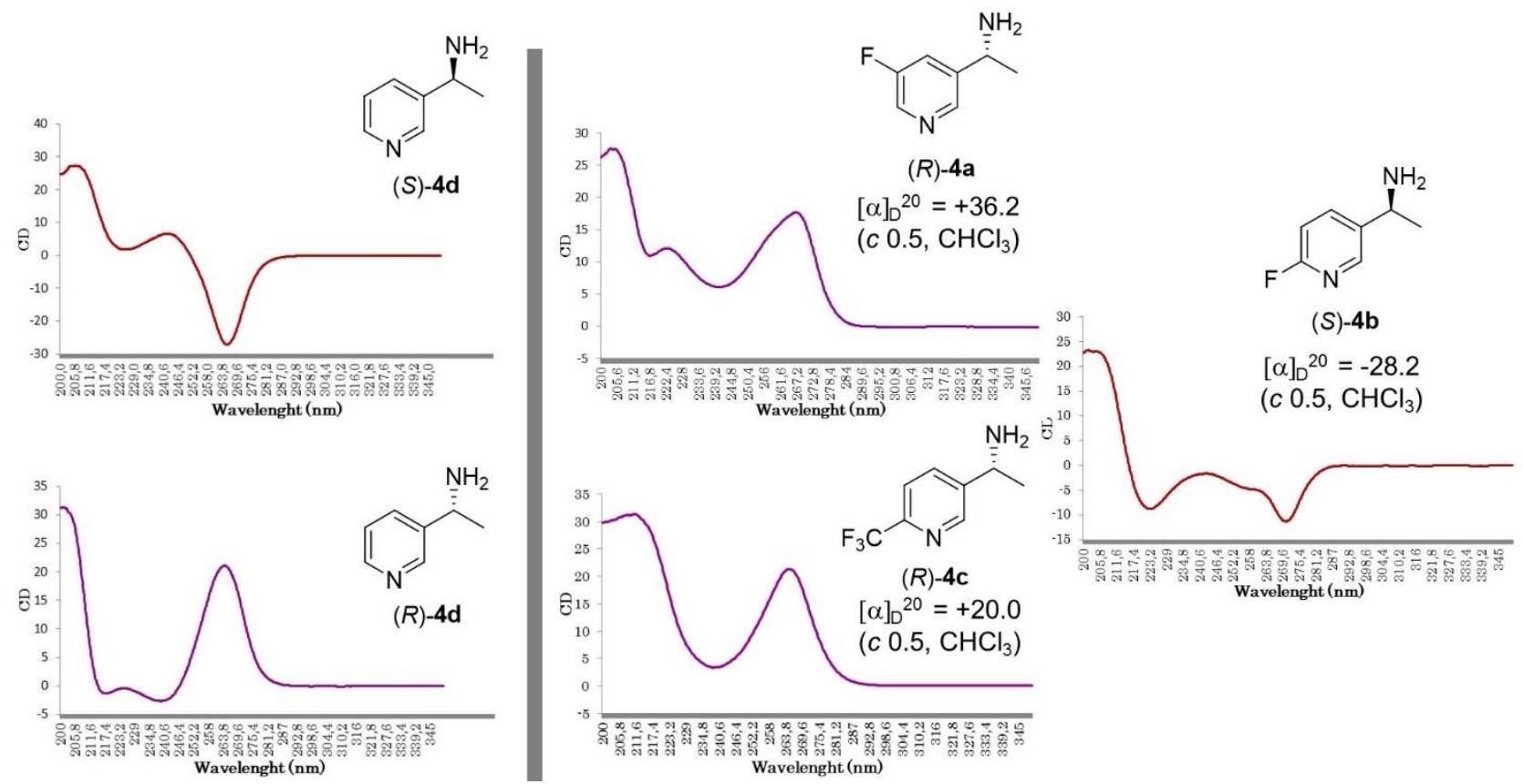

Figure 1. CD spectra recorded for reference compounds $(S)$ - and $(R)-\mathbf{4 d}($ left), and enantiopure amines $(R)-\mathbf{4 a},(S)-\mathbf{4 b}$ and $(R)-\mathbf{4 c}$ (right) obtained through selected biotransamination reactions. Optical rotation values for amines $\mathbf{4 a - c}$ in $>99 \% e e$ : $[\alpha]_{\mathrm{D}}^{20}=+36.2\left(c 0.5, \mathrm{CHCl}_{3}\right)$ for $(R)-\mathbf{4 a} ;[\alpha]_{\mathrm{D}}{ }^{20}=-28.2\left(c 0.5, \mathrm{CHCl}_{3}\right)$ for $(S)-\mathbf{4 b} ;[\alpha]_{\mathrm{D}}{ }^{20}=+20.0\left(c 0.5, \mathrm{CHCl}_{3}\right)$ for $(R)-\mathbf{4} \mathbf{c}$ 


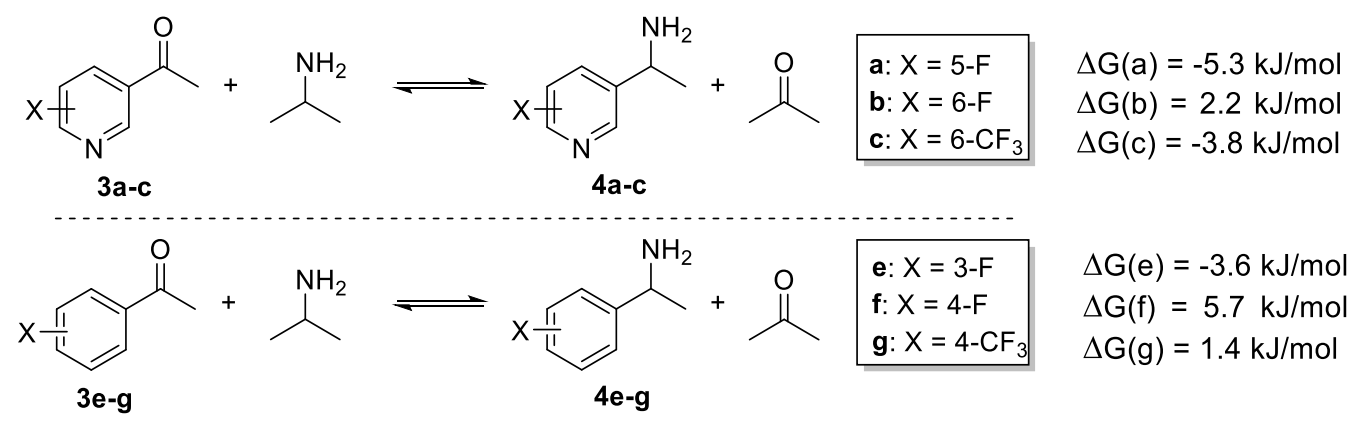

Scheme 2. Global Gibbs free reaction energy in the transamination of ketones 3a-c,e-g and 2-propylamine calculated at the M06-2X/6-311++G(3df,2p) level.

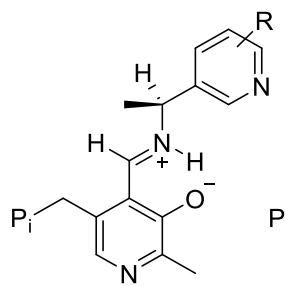

External aldimine (A)

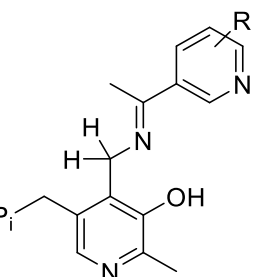

Ketimine (K)

$$
\mathrm{R}=5-\mathrm{F} ; 6-\mathrm{F} ; 6-\mathrm{CF}_{3}
$$

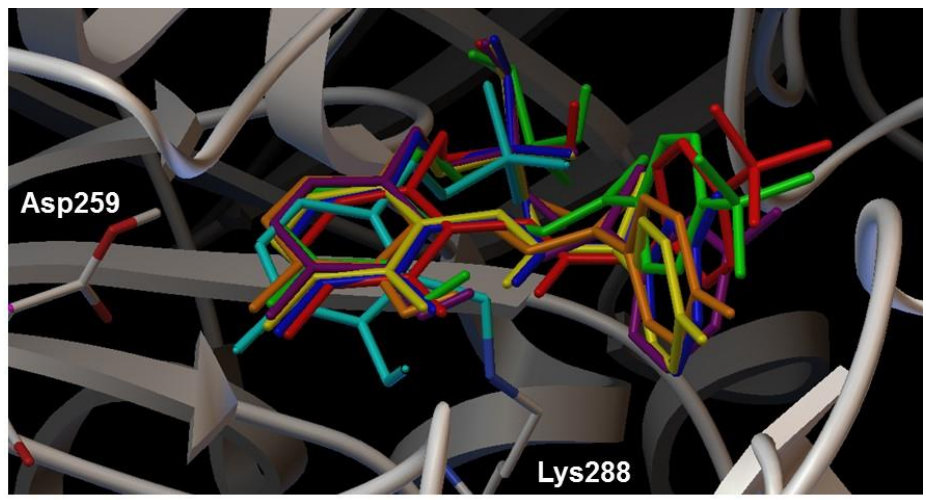

Figure 2. Key intermediates in the transamination mechanism (left); and the crystallographic position of the PLP in complex with Lys288 (light blue) and the docked conformations of the aldimines and ketimines in the active site of Chromobacterium violaceum TA with substitutions: 5-F (A-dark blue; K-purple), 6-F (A-yellow; K-orange) and 6-CF 3 (Ared; K-green).

The ONIOM(M06-2X/6-31G(d,p):Amber) method was employed to optimize the active site geometries of each docked intermediate (Figures S5 and S6), after which a non covalent interaction analysis was carried out with NCIPLOT ${ }^{[32]}$ in order to highlight the main interactions between the pyridines and the closest residues of the TA active site (Figure S7).

The previous model of the active site was employed for a new DFT calculation at the M062X/6-31G(d,p) level of theory in order to obtain the wavefunction of the optimized geometry and perform a frequency computation (Figure S8 and Table S6). The non-covalent interactions around the substrate were computed with NCIPLOT using the SCF densities (Figure S9 and Table S7). Figure 3 shows the enlargement of the zone where the most representative non covalent interactions where found for each substrate, appearing the weak attractive interactions in green, while the strongest ones are shown in blue. The difference of energy between the two intermediates within the active site was found to be favourable for the ketimine in $3 \mathbf{a}(-11.2 \mathrm{~kJ} / \mathrm{mol})$ and $3 \mathbf{c}(-6.0 \mathrm{~kJ} / \mathrm{mol})$, which is in agreement with the results reported by Cassimjee et al. for acetophenone transamination. ${ }^{[30]}$ On the contrary, the aldimine of $\mathbf{3 b}$ was more stable than the corresponding ketimine, with an energy difference of $18.9 \mathrm{~kJ} / \mathrm{mol}$.

The nitrogen of the 5-F substituted pyridine forms a strong hydrogen bond with the indole $\mathrm{N}-\mathrm{H}$ of tryptophan 60 (Figures 3A-B), which is also present on the 6-F substituted pyridine but displaying a slightly weaker bond strength (Figure 3C-D). Specifically, the hydrogen bond distances and angles are $2.16 \AA$ and $159.3^{\circ}$ for the 5-F-aldimine (Figure $3 \mathrm{~A}$ ), being the values $2.32 \AA$ and $156.5^{\circ}$ in the case of the 6-F-aldimine (Figure 3C). On the other hand, the distances are shorter in both the ketimine structures with values of $2.01 \AA\left(159.3^{\circ}\right)$ and $2.10 \AA$ $\left(154.4^{\circ}\right)$ for the $5-\mathrm{F}$ and $6-\mathrm{F}$ derivatives, respectively (Figures 3B and 3D). Besides, the 6-F-aldimine shows an additional $\mathrm{N}-\mathrm{H} \cdots \mathrm{F}$ bond with the arginine $416\left(2.11 \AA, 169.3^{\circ}\right)$, which could be responsible of the higher stabilization of the aldimine over the ketimine mentioned before.

Interestingly, the pyridine hydrogen bond is not observed in the hindered nitrogen atom of the $6-\mathrm{CF}_{3}$ aldimine derivative (Figure 3E) and it is weak in the corresponding ketimine derivative (2.54 A, Figure $3 \mathrm{~F}$ ), while a new strong interaction between two fluorine atoms and the Arg416 is responsible of these intermediates stabilization. Thus, three $\mathrm{N}-\mathrm{H} \cdots \mathrm{F}$ bonds were found in the aldimine between the two fluorine atoms mentioned before and two hydrogens of the residue (2.18 $\AA, 146.4^{\circ}$; $2.08 \AA, 143.1^{\circ}$; 2.02 $\AA, 136.0^{\circ}$; Figure 3E). For the corresponding ketimine (Figure 3F), non-hydrogen bond strong electrostatic interactions were established between the guanidinium cation and the trifluoromethyl group.

Despite the differences between the dispositions of the three studied substrates, all of them showed favourable interactions that enabled the transamination reaction smoothly within the active site of the TA from Chromobacterium violaceum. On the other hand, in contrast with our previous investigation with a set of pyridylalkylamines, ${ }^{[29]}$ in the present work the hydrogen bonds were 
established to be intermolecular between the

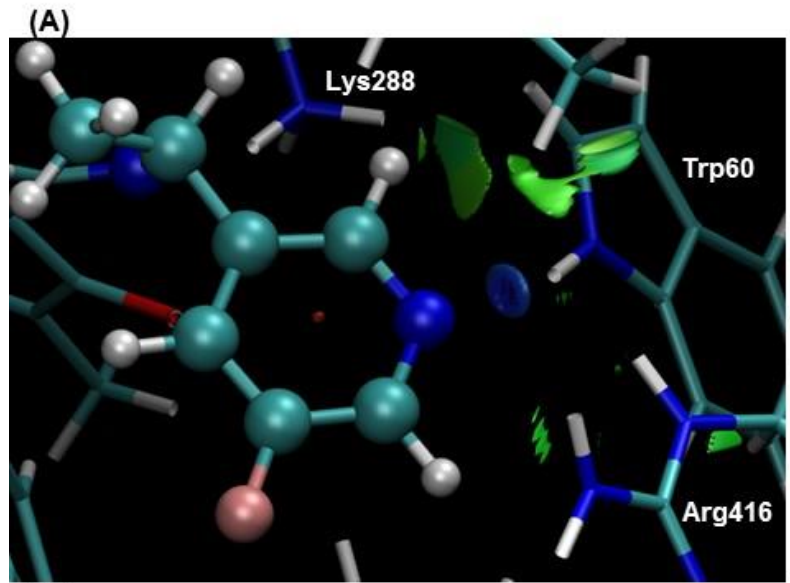

(C)

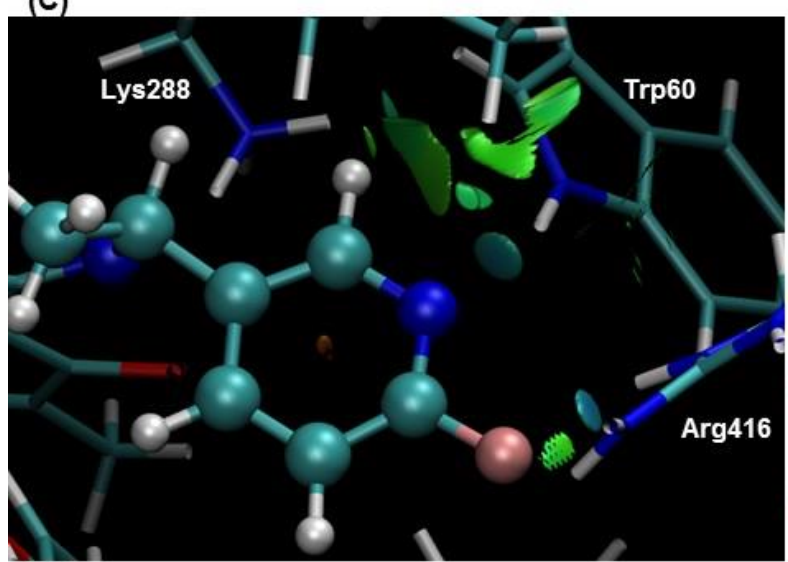

(E)

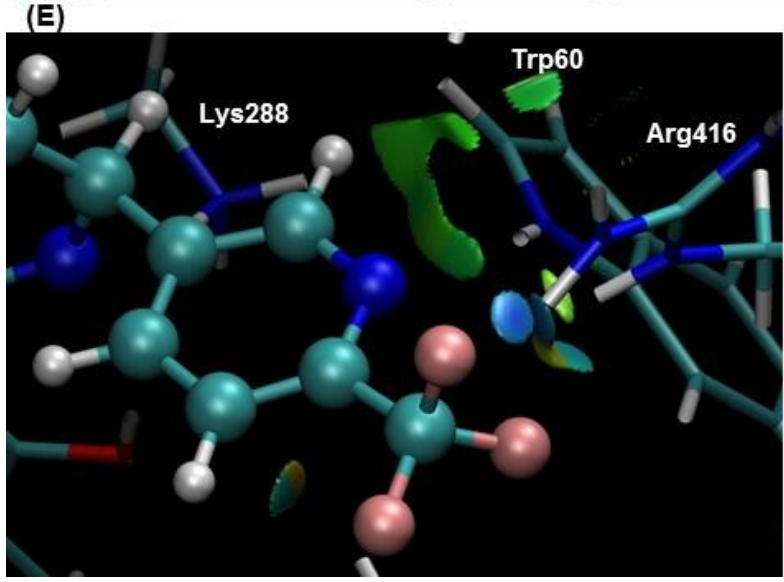

$(\mathbf{F}$

Figure 3. Non-covalent interaction analyses of the optimized geometry within the Chromobacterium violaceum TA active site of the aldimines with substitutions (A) 5-F; (C) 6-F; (E) 6- $\mathrm{CF}_{3}$; and the ketimines with substitutions (B) 5-F; (D) 6-F; (F) 6- $\mathrm{CF}_{3}$. Non-covalent attractive interactions appear in green (weak) or blue (strong) and the repulsive ones in red. Substrates are shown in ball-and-stick representation while the cofactor and the enzyme residues are shown as sticks.

\section{Conclusion}

Enzymes have been used in the asymmetric key-step for the synthesis of valuable fluorinated amines. The development of a straightforward synthetic pathway led to suitable substrates for lipase and transaminasecatalyzed transformations, which has made possible the preparation of a family of optically active pyridylethanamines bearing a fluorine atom at 5- or 6-position, or a trifluoromethyl group at 6-position.

On the one hand, classical kinetic resolutions through Candida antarctica lipase B-catalyzed

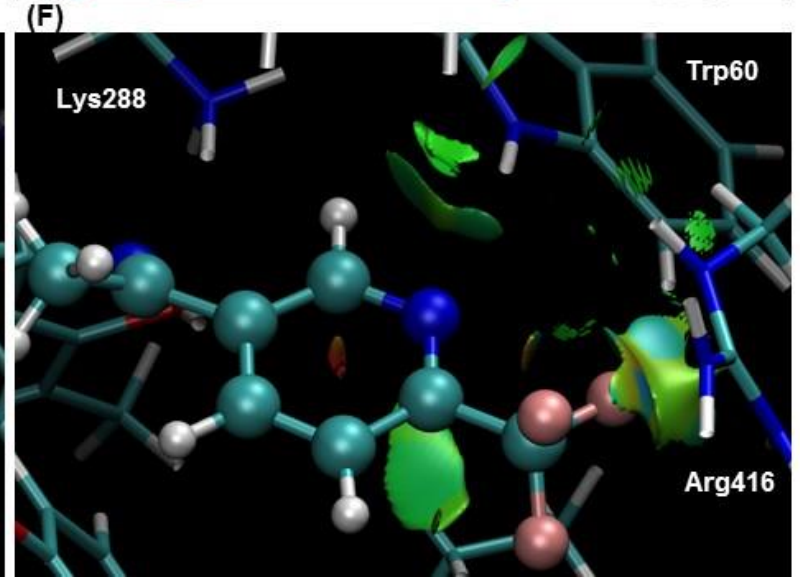

(B)

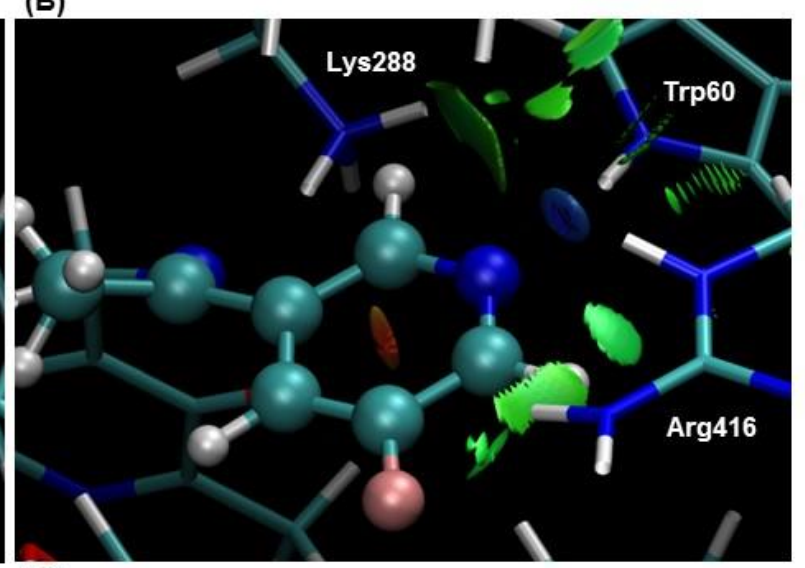

(D)

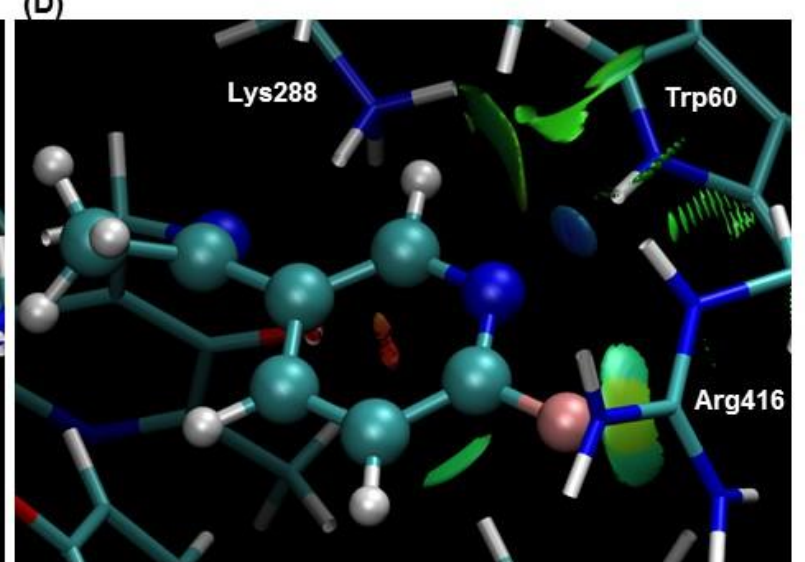

F) 
Transamination reactions have been investigated in depth in order to get a better understanding of the biocatalytic process through computational studies of the global equilibrium shift and the main interactions in the enzymatic active site. Thus, calculations confirmed that the presence of both the fluorine and the pyridyl nitrogen of the studied structures favoured the stabilization of the intermediates in the active site of the Chromobacterium violaceum TA through different non covalent interactions and therefore promoting the transamination reaction.

\section{Experimental Section}

\section{Enzyme activity}

Candida antarctica lipase type B (CAL-B, Novozym 435, $73000 \mathrm{PLU} / \mathrm{g}$ ) was kindly donated by Novozymes. TAs from Chromobacterium violaceum (2.1 U/mg), Vibrio fluvialis (1.3 U/mg), Arthrobacter citreus (0.9 U/mg) and Arthrobacter species (2.2 U/mg) were overexpressed in E.coli and used as lyophilized cells, while the evolved TA ArRmut11 (16 U/mg) was overexpressed in E.coli and purified by a heat protocol. See supporting Information for further details.

\section{General procedure for the synthesis of the alcohols $2 \mathrm{a}$ and $2 \mathrm{~b}$.}

A 1.6 M solution of ${ }^{n} \mathrm{BuLi}$ in $\mathrm{n}$-hexane $(1.76 \mathrm{~mL}, 2.81$ mmol) was added dropwise to a solution of the corresponding bromopyridine $1 \mathbf{a}$ or $\mathbf{1 b}(450.5 \mathrm{mg}, 2.56$ mmol) in anhydrous $\mathrm{Et}_{2} \mathrm{O}(13 \mathrm{~mL})$ at $-78^{\circ} \mathrm{C}$ under argon atmosphere. The mixture was stirred at that temperature for $30 \mathrm{~min}$. Then, a solution of acetaldehyde $(360 \mu \mathrm{L}, 6.39$ $\mathrm{mmol})$ in anhydrous $\mathrm{Et}_{2} \mathrm{O}(1 \mathrm{~mL})$ was slowly added to the resulting yellow suspension maintaining the inert atmosphere. The resulting solution was stirred at $-78^{\circ} \mathrm{C}$ for additional $1.5 \mathrm{~h}$. After this time, $\mathrm{H}_{2} \mathrm{O}(10 \mathrm{~mL})$ was added, leading to an orange suspension that was allowed to reach room temperature. Then, an aqueous $\mathrm{HCl} 1 \mathrm{M}$ solution was added until $\mathrm{pH} 8$ and the product was extracted with $\mathrm{Et}_{2} \mathrm{O}$ $(8 \times 10 \mathrm{~mL})$. The organic layers were combined, dried over $\mathrm{Na}_{2} \mathrm{SO}_{4}$, filtered and the solvent removed by distillation under reduced pressure. The reaction crude was purified by column chromatography on silica gel $(80 \%$ EtOAc/Hexane) to afford the alcohols $\mathbf{2 a}$ and $\mathbf{2} \mathbf{b}$ as yellow oils $(48-68 \%)$.

1-(5-Fluoropyridin-3-yl)ethan-1-ol (2a). Light yellow oil-solid. $48 \%$ Yield. ${ }^{1} \mathrm{H}$ NMR $\left(300.13 \mathrm{MHz}, \mathrm{CDCl}_{3}\right): \delta$ $1.40\left(\mathrm{~d},{ }^{3} J_{\mathrm{HH}}=6.5 \mathrm{~Hz}, 3 \mathrm{H}, \mathrm{H}_{2}\right), 4.86\left(\mathrm{q},{ }^{3} \mathrm{~J}_{\mathrm{HH}}=6.5 \mathrm{~Hz}, 1 \mathrm{H}\right.$, $\left.\mathrm{H}_{1}\right), 5.05$ (brs, $\left.1 \mathrm{H}, \mathrm{OH}\right), 7.41\left(\mathrm{dt},{ }^{3} J_{\mathrm{FH}}=9.3 \mathrm{~Hz},{ }^{4} J_{\mathrm{HH}}=2.2\right.$ $\left.\mathrm{Hz}, 1 \mathrm{H}, \mathrm{H}_{4}\right), 8.12\left(\mathrm{~d},{ }^{4} J_{\mathrm{HH}}=2.6 \mathrm{~Hz}, 1 \mathrm{H}, \mathrm{H}_{6}\right), 8.18(\mathrm{~s}, 1 \mathrm{H}$, $\left.\mathrm{H}_{2},\right) \mathrm{ppm} .{ }^{13} \mathrm{C}$ NMR $\left(75.5 \mathrm{MHz}, \mathrm{CDCl}_{3}\right): \delta 25.3\left(\mathrm{CH}_{3}, \mathrm{C}_{2}\right)$, $66.9\left(\mathrm{CH}, \mathrm{C}_{1}\right), 120.4\left(\mathrm{~d},{ }^{2} J_{\mathrm{FC}}=18.3 \mathrm{~Hz}, \mathrm{CH}, \mathrm{C}_{4}\right), 136.4(\mathrm{~d}$, $\left.{ }^{2} J_{\mathrm{FC}}=24.0 \mathrm{~Hz}, \mathrm{CH}, \mathrm{C}_{6}\right), 142.8\left(\mathrm{~d},{ }^{4} J_{\mathrm{FC}}=3.6 \mathrm{~Hz}, \mathrm{CH}, \mathrm{C}_{2}{ }^{\prime}\right)$, $144.0\left(\mathrm{~d},{ }^{3} J_{\mathrm{FC}}=2.5 \mathrm{~Hz}, \mathrm{C}, \mathrm{C}_{3},\right), 159.8\left(\mathrm{~d},{ }^{1} J_{\mathrm{FC}}=258.1 \mathrm{~Hz}\right.$, $\mathrm{C}, \mathrm{C}_{5}, \mathrm{p} \mathrm{ppm}$. HRMS $\left(\mathrm{ESI}^{+}, \mathrm{m} / \mathrm{z}\right)$ : calcd for $\left(\mathrm{C}_{7} \mathrm{H}_{9} \mathrm{FNO}\right)^{+}$ $(\mathrm{M}+\mathrm{H})^{+}: 142.0663$, found: 142.0674 .

1-(6-Fluoropyridin-3-yl)ethan-1-ol (2b). Light yellow oil-solid. 68\% Yield. ${ }^{1} \mathrm{H}$ NMR (300.13 MHz, $\left.\mathrm{CDCl}_{3}\right): \delta$ $1.45\left(\mathrm{~d},{ }^{3} J_{\mathrm{HH}}=6.5 \mathrm{~Hz}, 3 \mathrm{H}, \mathrm{H}_{2}\right), 3.46(\mathrm{brs}, 1 \mathrm{H}, \mathrm{OH}), 4.90(\mathrm{q}$, $\left.{ }^{3} J_{\mathrm{HH}}=6.5 \mathrm{~Hz}, 1 \mathrm{H}, \mathrm{H}_{1}\right), 6.86\left(\mathrm{dd},{ }^{3} J_{\mathrm{HH}}=8.4 \mathrm{~Hz},{ }^{3} J_{\mathrm{FH}}=2.7\right.$ $\left.\mathrm{Hz}, 1 \mathrm{H}, \mathrm{H}_{5}\right), 7.80\left(\mathrm{dt},{ }^{3} \mathrm{~J}_{\mathrm{HH}}=8.1 \mathrm{~Hz},{ }^{4} J_{\mathrm{FH}}=8.1 \mathrm{~Hz},{ }^{4} J_{\mathrm{HH}}=\right.$
$\left.2.5 \mathrm{~Hz}, 1 \mathrm{H}, \mathrm{H}_{4}\right), 8.06\left(\mathrm{~s}, 1 \mathrm{H}, \mathrm{H}_{2}, \mathrm{ppm}^{13} \mathrm{C} \mathrm{NMR}(75.5\right.$ $\left.\mathrm{MHz}, \mathrm{CDCl}_{3}\right): \delta 25.3\left(\mathrm{CH}_{3}, \mathrm{C}_{2}\right), 67.2\left(\mathrm{CH}, \mathrm{C}_{1}\right), 109.5(\mathrm{~d}$, $\left.{ }^{2} J_{\mathrm{FC}}=36.9 \mathrm{~Hz}, \mathrm{CH}, \mathrm{C}_{5}\right), 139.0\left(\mathrm{~d},{ }^{3} J_{\mathrm{FC}}=8.0 \mathrm{~Hz}, \mathrm{CH}, \mathrm{C}_{4}{ }^{\prime}\right)$, $139.1\left(\mathrm{~d},{ }^{4} J_{\mathrm{FC}}=4.4 \mathrm{~Hz}, \mathrm{C}, \mathrm{C}_{3}\right), 144.7\left(\mathrm{~d},{ }^{3} J_{\mathrm{FC}}=14.2 \mathrm{~Hz}\right.$, $\left.\mathrm{CH}, \mathrm{C}_{2}{ }^{\prime}\right), 162.9\left(\mathrm{~d},{ }^{1} J_{\mathrm{FC}}=238.9 \mathrm{~Hz}, \mathrm{C}, \mathrm{C}_{6}\right.$ ) ppm. HRMS $\left(\mathrm{ESI}^{+}, \mathrm{m} / \mathrm{z}\right)$ : calcd for $\left(\mathrm{C}_{7} \mathrm{H}_{9} \mathrm{FNO}\right)^{+}(\mathrm{M}+\mathrm{H})^{+}: 142.0663$, found: 142.0660 .
General procedure for the synthesis of the ketones $3 a$ and $3 b$.

Dess-Martin reagent $(2.65 \mathrm{~g}, 6.25 \mathrm{mmol})$ was added to a solution of the corresponding alcohols $2 \mathbf{a}$ or $\mathbf{2 b}(0.589 \mathrm{~g}$, $4.17 \mathrm{mmol})$ in $\mathrm{CH}_{2} \mathrm{Cl}_{2}(42 \mathrm{~mL})$. The mixture was stirred at room temperature for $2 \mathrm{~h}$. After this time, the reaction was quenched by adding an aqueous $\mathrm{NaHCO}_{3} / \mathrm{Na}_{2} \mathrm{~S}_{2} \mathrm{O}_{3}$ solution (20 mL, 1:1 v/v of aqueous saturated solutions) and stirred for additional $5 \mathrm{~min}$ until complete disappearance of the solid. The mixture was extracted with $\mathrm{CH}_{2} \mathrm{Cl}_{2}(3 \times 20 \mathrm{~mL})$, the organic layers were combined, dried over $\mathrm{Na}_{2} \mathrm{SO}_{4}$, filtered and the solvent removed by distillation under reduced pressure to afford the ketones $\mathbf{3 a}$ and $\mathbf{3 b}$ as yellow solids $(85-95 \%)$.

1-(5-Fluoropyridin-3-yl)ethan-1-one (3a). Yellow solid. $85 \%$ Yield. Mp: $48-50{ }^{\circ} \mathrm{C}$. ${ }^{1} \mathrm{H}$ NMR $(300.13 \mathrm{MHz}$, $\left.\mathrm{CDCl}_{3}\right): \delta 2.64\left(\mathrm{~s}, 3 \mathrm{H}, \mathrm{H}_{2}\right), 7.90\left(\mathrm{ddd},{ }^{3} J_{\mathrm{FH}}=8.7 \mathrm{~Hz},{ }^{4} J_{\mathrm{HH}}=\right.$ $2.8 \mathrm{~Hz},{ }^{4} J_{\mathrm{HH}}=1.7 \mathrm{~Hz}, 1 \mathrm{H}, \mathrm{H}_{4}, 8.63\left(\mathrm{~d},{ }^{4} J_{\mathrm{HH}}=2.7 \mathrm{~Hz}, 1 \mathrm{H}\right.$, $\mathrm{H}_{6}$ ), 8.96 (s, 1H, H ${ }_{2}$ ) ppm. ${ }^{13} \mathrm{C}$ NMR $\left(75.5 \mathrm{MHz} \mathrm{CDCl}_{3}\right)$ : $\delta 27.1\left(\mathrm{CH}_{3}, \mathrm{C}_{2}\right), 121.8\left(\mathrm{~d},{ }^{2} J_{\mathrm{FC}}=18.7 \mathrm{~Hz}, \mathrm{CH}, \mathrm{C}_{4}\right), 133.7$ $\left(\mathrm{C}, \mathrm{C}_{3},\right), 142.4\left(\mathrm{~d},{ }^{2} J_{\mathrm{FC}}=23.6 \mathrm{~Hz}, \mathrm{CH}, \mathrm{C}_{6}\right), 145.7\left(\mathrm{~d},{ }^{4} J_{\mathrm{FC}}=\right.$ $4.0 \mathrm{~Hz}, \mathrm{CH}, \mathrm{C}_{2}$ ) $, 159.6\left(\mathrm{~d},{ }^{1} J_{\mathrm{FC}}=259.4 \mathrm{~Hz}, \mathrm{C}, \mathrm{C}_{5}\right.$ ) $), 195.4$ $\left(\mathrm{C}, \mathrm{C}_{1}\right) \mathrm{ppm}$. HRMS $\left(\mathrm{ESI}^{+}, \mathrm{m} / \mathrm{z}\right)$ : calcd for $\left(\mathrm{C}_{7} \mathrm{H}_{7} \mathrm{FNO}\right)^{+}$ $(\mathrm{M}+\mathrm{H})^{+}:$140.0506, found: 140.0510 .

1-(6-Fluoropyridin-3-yl)ethan-1-one (3b). Yellow solid. 95\% Yield. Mp: $47-49^{\circ} \mathrm{C}$. ${ }^{1} \mathrm{H}$ NMR $(300.13 \mathrm{MHz}$, $\left.\mathrm{CDCl}_{3}\right): \delta 2.62\left(\mathrm{~s}, 3 \mathrm{H}, \mathrm{H}_{2}\right), 7.02\left(\mathrm{dd},{ }^{3} J_{\mathrm{HH}}=8.5 \mathrm{~Hz},{ }^{3} J_{\mathrm{FH}}=\right.$ $\left.2.6 \mathrm{~Hz}, 1 \mathrm{H}, \mathrm{H}_{5},\right), 8.36\left(\mathrm{ddd},{ }^{3} J_{\mathrm{HH}}=8.5 \mathrm{~Hz},{ }^{4} J_{\mathrm{FH}}=7.7 \mathrm{~Hz}\right.$, $\left.{ }^{4} J_{\mathrm{HH}}=2.6 \mathrm{~Hz}, 1 \mathrm{H}, \mathrm{H}_{4},\right), 8.80\left(\mathrm{~d},{ }^{4} J_{\mathrm{HH}}=2.4 \mathrm{~Hz}, 1 \mathrm{H}, \mathrm{H}_{2},\right)$ ppm. ${ }^{13} \mathrm{C}$ NMR (75.5 MHz, $\left.\mathrm{CDCl}_{3}\right): \delta 26.8\left(\mathrm{CH}_{3}, \mathrm{C}_{2}\right)$, $110.1\left(\mathrm{~d},{ }^{2} J_{\mathrm{FC}}=37.3 \mathrm{~Hz}, \mathrm{CH}, \mathrm{C}_{5}\right), 131.1\left(\mathrm{~d},{ }^{4} J_{\mathrm{FC}}=4.4 \mathrm{~Hz}\right.$, C, $\left.\mathrm{C}_{3},{ }\right), 141.3\left(\mathrm{~d},{ }^{3} J_{\mathrm{FC}}=9.4 \mathrm{~Hz}, \mathrm{CH}, \mathrm{C}_{4}\right), 149.5\left(\mathrm{~d},{ }^{3} J_{\mathrm{FC}}=\right.$ $16.4 \mathrm{~Hz}, \mathrm{CH}, \mathrm{C}_{2}$ ), $165.7\left(\mathrm{~d},{ }^{1} J_{\mathrm{FC}}=246.4 \mathrm{~Hz}, \mathrm{C}, \mathrm{C}_{6}\right.$ ), 195.0 $\left(\mathrm{C}, \mathrm{C}_{1}\right) \mathrm{ppm}$. HRMS $\left(\mathrm{ESI}^{+}, \mathrm{m} / \mathrm{z}\right)$ : calcd for $\left(\mathrm{C}_{7} \mathrm{H}_{7} \mathrm{FNO}\right)^{+}$ $(\mathrm{M}+\mathrm{H})^{+}:$140.0506, found: 140.0512 .

\section{Procedure for the synthesis of 1-(6- Trifluoromethyl)pyridine-3-yl)ethan-1-one (3c).}

A $3 \mathrm{M}$ solution of methylmagnesium iodide in $\mathrm{Et}_{2} \mathrm{O}(2.4$ $\mathrm{mL}, 7.34 \mathrm{mmol}$ ) was added dropwise to a solution of the carbonitrile 5 (317 mg, $1.84 \mathrm{mmol})$ in anhydrous $\mathrm{Et}_{2} \mathrm{O}$ $(6.11 \mathrm{~mL})$ at $0{ }^{\circ} \mathrm{C}$ and under nitrogen atmosphere. An extra millilitre of anhydrous $\mathrm{Et}_{2} \mathrm{O}$ was added to drag out the organomagnesium reagent remaining in the addition funnel, and the mixture was stirred at room temperature for $4 \mathrm{~h}$. A colour change was observed from the starting yellow solution to an intense dark red one during this time. The reaction was poured into a saturated aqueous $\mathrm{NH}_{4} \mathrm{Cl}$ solution $(6 \mathrm{~mL})$ at $0{ }^{\circ} \mathrm{C}$ and $\mathrm{HCl}$ conc. was added until strong acid medium $(\mathrm{pH} 1)$. The resulting mixture was stirred overnight at room temperature and then basified until $\mathrm{pH} 9$ by addition of an aqueous $\mathrm{NH}_{3}$ solution. The reaction was extracted with $\mathrm{Et}_{2} \mathrm{O}(3 \mathrm{x} 15 \mathrm{~mL})$, the combined organic layers were dried over $\mathrm{Na}_{2} \mathrm{SO}_{4}$, filtered and the solvent removed by distillation under reduced pressure. The crude product was purified by column chromatography on silica gel $(20 \%$ EtOAc/Hexane) to afford the ketone $3 \mathrm{c}$ as a pale yellow solid $(153 \mathrm{mg}, 44 \%)$ Mp: 57-59 ${ }^{\circ} \mathrm{C}$. ${ }^{1} \mathrm{H}$ NMR $\left(300.13 \mathrm{MHz}, \mathrm{CDCl}_{3}\right): \delta 2.69$ (s, $\left.3 \mathrm{H}, \mathrm{H}_{2}\right), 7.81\left(\mathrm{~d},{ }^{3} J_{\mathrm{HH}}=8.0 \mathrm{~Hz}, 1 \mathrm{H}, \mathrm{H}_{5},\right), 8.40\left(\mathrm{dd},{ }^{3} J_{\mathrm{HH}}=\right.$ $\left.8.1 \mathrm{~Hz},{ }^{4} J_{\mathrm{HH}}=1.6 \mathrm{~Hz}, 1 \mathrm{H}, \mathrm{H}_{4},\right), 9.17\left(\mathrm{~d},{ }^{4} J_{\mathrm{HH}}=1.3 \mathrm{~Hz}, 1 \mathrm{H}\right.$, $\mathrm{H}_{2}$ ) ppm. ${ }^{3} \mathrm{C}$ NMR $\left(75.5 \mathrm{MHz}, \mathrm{CDCl}_{3}\right): \delta 27.1\left(\mathrm{CH}_{3}, \mathrm{C}_{2}\right)$, $120.7\left(\mathrm{~d},{ }^{4} J_{\mathrm{FC}}=2.5 \mathrm{~Hz}, \mathrm{CH}, \mathrm{C}_{5},\right), 121.2\left(\mathrm{q},{ }^{1} J_{\mathrm{FC}}=274.6 \mathrm{~Hz}\right.$, $\left.\mathrm{C}, \mathrm{CF}_{3}\right), 134.0\left(\mathrm{C}, \mathrm{C}_{3}{ }^{\prime}\right), 137.3\left(\mathrm{CH}, \mathrm{C}_{4}{ }^{\prime}\right), 150.0\left(\mathrm{CH}, \mathrm{C}_{2}{ }^{\prime}\right)$, $151.3\left(\mathrm{q},{ }^{2} J_{\mathrm{FC}}=35.2 \mathrm{~Hz}, \mathrm{C}, \mathrm{C}_{6}\right), 195.6\left(\mathrm{C}, \mathrm{C}_{1}\right) \mathrm{ppm}$ $\mathrm{HRMS}\left(\mathrm{ESI}^{+}, \mathrm{m} / \mathrm{z}\right)$ : calcd for $\left(\mathrm{C}_{8} \mathrm{H}_{7} \mathrm{~F}_{3} \mathrm{NO}\right)^{+}(\mathrm{M}+\mathrm{H})^{+}$: 190.0474, found: 190.0479 .

General procedure for the synthesis of the racemic amines $4 a-c$.

Ammonium acetate $(335 \mathrm{mg}, 4.34 \mathrm{mmol}$ ) and sodium cyanoborohydride $(55 \mathrm{mg}, 0.87 \mathrm{mmol})$ were added to a solution of the corresponding ketone 3a-c $(0.43 \mathrm{mmol})$ in anhydrous $\mathrm{MeOH}(1.4 \mathrm{~mL})$. The resulting mixture was stirred during $14 \mathrm{~h}$ at room temperature. After this time, 
the solvent was removed by distillation under reduced pressure and the reaction crude was purified by column chromatography on silica gel (5\% $\left.\mathrm{MeOH} / \mathrm{CH}_{2} \mathrm{Cl}_{2}\right)$, yielding the corresponding racemic amines 4a-c (40-55\%) as yellow oils.

1-(5-Fluoropyridin-3-yl)ethan-1-amine (4a). Yellow oil. $47 \%$ Yield. ${ }^{1} \mathrm{H}$ NMR $\left(300.13 \mathrm{MHz}, \mathrm{CDCl}_{3}\right): \delta 1.38(\mathrm{~d}$, $\left.{ }^{3} J_{\mathrm{HH}}=6.6 \mathrm{~Hz}, 3 \mathrm{H}, \mathrm{H}_{2}\right), 1.82\left(\mathrm{bs}, 2 \mathrm{H}, \mathrm{NH}_{2}\right), 4.21\left(\mathrm{q},{ }^{3} J_{\mathrm{HH}}=\right.$ $\left.6.6 \mathrm{~Hz}, 1 \mathrm{H}, \mathrm{H}_{1}\right), 7.45\left(\mathrm{dt},{ }^{3} J_{\mathrm{FH}}=9.6 \mathrm{~Hz},{ }^{4} J_{\mathrm{HH}}=2.0 \mathrm{~Hz}, 1 \mathrm{H}\right.$, $\left.\mathrm{H}_{4}\right), 8.32\left(\mathrm{~d},{ }^{4} J_{\mathrm{HH}}=2.8 \mathrm{~Hz}, 1 \mathrm{H}, \mathrm{H}_{6},\right), 8.38\left(\mathrm{t},{ }^{4} J_{\mathrm{HH}}=1.8 \mathrm{~Hz}\right.$, $\left.1 \mathrm{H}, \mathrm{H}_{2},\right) \mathrm{ppm} .{ }^{13} \mathrm{C} \mathrm{NMR}\left(75.5 \mathrm{MHz}, \mathrm{CDCl}_{3}\right): \delta 25.8\left(\mathrm{CH}_{3}\right.$, $\left.\left.\mathrm{C}_{2}\right), 48.6\left(\mathrm{CH}, \mathrm{C}_{1}\right), 120.3\left(\mathrm{~d},{ }^{2} J_{\mathrm{FC}}=18.1 \mathrm{~Hz}, \mathrm{CH}, \mathrm{C}_{4}\right)^{\prime}\right)$, $136.7\left(\mathrm{~d},{ }^{2} J_{\mathrm{FC}}=23.4 \mathrm{~Hz}, \mathrm{CH}, \mathrm{C}_{6}\right), 143.9\left(\mathrm{~d},{ }^{4} J_{\mathrm{FC}}=3.7 \mathrm{~Hz}\right.$, $\mathrm{CH}, \mathrm{C}_{2}$ ) $144.8\left(\mathrm{C}, \mathrm{C}_{3},\right), 159.9\left(\mathrm{~d},{ }^{1}{ }^{1} J_{\mathrm{FC}}=256.5 \mathrm{~Hz}, \mathrm{C}, \mathrm{C}_{5}\right.$, ppm. HRMS $\left(\mathrm{ESI}^{+}, \mathrm{m} / \mathrm{z}\right)$ : calcd for $\left(\mathrm{C}_{7} \mathrm{H}_{10} \mathrm{FN}_{2}\right)^{+}(\mathrm{M}+\mathrm{H})^{+}$: 141.0823, found: 141.0823 .

1-(6-Fluoropyridin-3-yl)ethan-1-amine (4b). Yellow oil. $55 \%$ Yield. ${ }^{1} \mathrm{H}$ NMR $\left(300.13 \mathrm{MHz}, \mathrm{CDCl}_{3}\right): \delta 1.39(\mathrm{~d}$, $\left.{ }^{3} J_{\mathrm{HH}}=6.6 \mathrm{~Hz}, 3 \mathrm{H}, \mathrm{H}_{1}\right), 1.94\left(\mathrm{brs}, 2 \mathrm{H}, \mathrm{NH}_{2}\right), 4.38\left(1 \mathrm{H}, \mathrm{H}_{1}\right)$, $6.88\left(\mathrm{dd},{ }^{3} J_{\mathrm{HH}}=8.5 \mathrm{~Hz},{ }^{3} J_{\mathrm{FH}}=2.5 \mathrm{~Hz}, 1 \mathrm{H}, \mathrm{H}_{5}, 7.83(\mathrm{dt}\right.$, $\left.{ }^{3} J_{\mathrm{HH}}=8.1 \mathrm{~Hz},{ }^{4} J_{\mathrm{FH}}=8.1 \mathrm{~Hz},{ }^{4} J_{\mathrm{HH}}=2.5 \mathrm{~Hz}, 1 \mathrm{H}, \mathrm{H}_{4},\right), 8.16$ $\left(\mathrm{d},{ }^{4} J_{\mathrm{HH}}=2.0 \mathrm{~Hz}, 1 \mathrm{H}, \mathrm{H}_{2},\right) \mathrm{ppm} \cdot{ }^{13} \mathrm{C}$ NMR $(75.5 \mathrm{MHz}$, $\left.\mathrm{CDCl}_{3}\right): \delta 21.2\left(\mathrm{CH}_{3}, \mathrm{C}_{2}\right), 48.1\left(\mathrm{CH}, \mathrm{C}_{1}\right), 110.0\left(\mathrm{~d},{ }^{2} J_{\mathrm{FC}}=\right.$ $37.5 \mathrm{~Hz}, \mathrm{CH}, \mathrm{C}_{5}$ ), $140.0\left(\mathrm{C}, \mathrm{C}_{3}\right.$ ), $140.1\left(\mathrm{~d},{ }^{3} J_{\mathrm{FC}}=8.1 \mathrm{~Hz}\right.$, $\left.\mathrm{CH}, \mathrm{C}_{4}\right), 146.6\left(\mathrm{~d},{ }^{3} J_{\mathrm{FC}}=14.8 \mathrm{~Hz}, \mathrm{CH}, \mathrm{C}_{2}\right), 163.5\left(\mathrm{~d},{ }^{1} J_{\mathrm{FC}}\right.$ $=240.2 \mathrm{~Hz}, \mathrm{C}, \mathrm{C}_{6}, \mathrm{ppm}_{\text {. HRMS }}\left(\mathrm{ESI}^{+}, \mathrm{m} / \mathrm{z}\right)$ : calcd for $\left(\mathrm{C}_{7} \mathrm{H}_{10} \mathrm{FN}_{2}\right)^{+}(\mathrm{M}+\mathrm{H})^{+}:$141.0823, found: 141.0835 .

1-(6-Trifluoromethyl)pyridine-3-yl)ethan-1-amine (4c). Yellow oil. 40\% Yield. ${ }^{1} \mathrm{H}$ NMR $(300.13 \mathrm{MHz}$, $\left.\mathrm{CDCl}_{3}\right): \delta 1.41\left(\mathrm{~d},{ }^{3} J_{\mathrm{HH}}=6.6 \mathrm{~Hz}, 3 \mathrm{H}, \mathrm{H}_{2}\right), 4.27\left(\mathrm{q},{ }^{3} J_{\mathrm{HH}}=\right.$ $\left.6.6 \mathrm{~Hz}, 1 \mathrm{H}, \mathrm{H}_{1}\right), 7.63\left(\mathrm{~d},{ }^{3} J_{\mathrm{HH}}=8.1 \mathrm{~Hz}, 1 \mathrm{H}, \mathrm{H}_{5}, 7.90(\mathrm{dd}\right.$, $\left.{ }^{3} J_{\mathrm{HH}}=8.1 \mathrm{~Hz},{ }^{4} J_{\mathrm{HH}}=2.0 \mathrm{~Hz}, 1 \mathrm{H}, \mathrm{H}_{4},\right), 8.68\left(\mathrm{~d},{ }^{4} J_{\mathrm{HH}}=2.0\right.$ $\mathrm{Hz}, 1 \mathrm{H}, \mathrm{H}_{2}$, ) ppm. ${ }^{13} \mathrm{C}$ NMR $\left(75.5 \mathrm{MHz}, \mathrm{CDCl}_{3}\right): \delta 22.2$ $\left(\mathrm{CH}_{3}, \mathrm{C}_{2}\right), 48.8\left(\mathrm{CH}, \mathrm{C}_{1}\right), 120.8\left(\mathrm{CH}, \mathrm{C}_{5}\right), 121.2\left(\mathrm{q},{ }^{1} \mathrm{~J}_{\mathrm{FC}}=\right.$ $\left.274.1 \mathrm{~Hz}, \mathrm{C}, \mathrm{CF}_{3}\right), 136.4\left(\mathrm{CH}, \mathrm{C}_{4}\right), 138.8\left(\mathrm{C}, \mathrm{C}_{3},\right), 148.2$ $\left(\mathrm{q}, \mathrm{C},{ }^{2} J_{\mathrm{FC}}=35.1 \mathrm{~Hz}, \mathrm{C}_{6}{ }^{\prime}\right), 148.9\left(\mathrm{CH}, \mathrm{C}_{2},\right) \mathrm{ppm}$. HRMS $\left(\mathrm{ESI}^{+}, \mathrm{m} / \mathrm{z}\right)$ : calcd for $\left(\mathrm{C}_{8} \mathrm{H}_{10} \mathrm{~F}_{3} \mathrm{~N}_{2}\right)^{+}(\mathrm{M}+\mathrm{H})^{+}$: 191.0791, found: 191.0787.

\section{General procedure for the kinetic resolution of amines $( \pm)-4 a-c$ through CAL-B-catalyzed acylation.}

Ethyl methoxyacetate (5 equiv) was added to a suspension containing the corresponding racemic amine 4a-c (40 mg) and the enzyme (CAL-B, $40 \mathrm{mg}$ ) in anhydrous THF $(0.1$ $\mathrm{M})$ under inert atmosphere. The reaction was shaken at 30 ${ }^{\circ} \mathrm{C}$ and $250 \mathrm{rpm}$ for the necessary time to achieve a good kinetic resolution (2-7 $\mathrm{h}$ for around $50 \%$ conversion, see Table 1), following the reaction timecourse by HPLC analysis. The enzyme was filtered off, washed with THF (5 $\mathrm{x} 1 \mathrm{~mL}$ ) and the solvent evaporated under reduced pressure. The reaction crude was purified by column chromatography on silica gel (eluent gradient $5-50 \%$ $\mathrm{MeOH} / \mathrm{CH}_{2} \mathrm{Cl}_{2}$ ), affording the corresponding optically active methoxyacetamides $(R)-\mathbf{6 a - c}(\mathbf{6 a}: 47 \%$ yield; 6b: $31 \%$ yield; $6 \mathbf{c}: 36 \%$ yield) and the remaining amines $(S)$ 4a-c (4a: $14 \%$ yield; 4b: $28 \%$ yield; $4 \mathbf{c}: 34 \%$ yield). For $(R)-6 a$ in $>99 \%$ ee: $[\alpha]_{\mathrm{D}}{ }^{20}=+68.9\left(c 1, \mathrm{CHCl}_{3}\right)$. For $(R)-$ 6b in $>99 \%$ ee: $[\alpha]_{\mathrm{D}}{ }^{20}=+61.4\left(c 0.5, \mathrm{CHCl}_{3}\right)$. For $(R)-\mathbf{6 c}$ in $>99 \%$ ee: $[\alpha]_{\mathrm{D}}^{20}=+56.5\left(c 1, \mathrm{CHCl}_{3}\right)$.

General procedure for the asymmetric transamination of ketones 3a-c employing lyophilized cells and alanine dehydrogenase as regeneration system.

The lyophilized cells of $E$. coli containing overexpressed transaminases $(20 \mathrm{mg})$ were suspended in a $100 \mathrm{mM}$ phosphate buffer $\mathrm{pH}^{7}(440 \mu \mathrm{L})$ and the mixture was stirred at $30^{\circ} \mathrm{C}$ and $120 \mathrm{rpm}$ for $30 \mathrm{~min}$. To the resulting suspension, the ketones 3a-c $(0.05 \mathrm{mmol}, 50 \mathrm{mM})$, ammonium formate $(100 \mu \mathrm{L}$ of $1.5 \mathrm{M}$ solution in a 100 $\mathrm{mM}$ phosphate buffer $\mathrm{pH} 7$; final concentration $150 \mathrm{mM}$ ), alanine $(250 \mu \mathrm{L}$ of $1 \mathrm{M}$ solution in phosphate buffer 100 $\mathrm{mM} \mathrm{pH} 7$; final concentration $250 \mathrm{mM}), \mathrm{NAD}^{+}(100 \mu \mathrm{L}$ of $10 \mathrm{mM}$ solution in a $100 \mathrm{mM}$ phosphate buffer $\mathrm{pH} 7$; final concentration $1 \mathrm{mM})$, PLP $(100 \mu \mathrm{L}$ of $10 \mathrm{mM}$ solution in a $100 \mathrm{mM}$ phosphate buffer $\mathrm{pH} 7$; final concentration $1 \mathrm{mM}$ ), formate dehydrogenase (FDH, $2.6 \mathrm{mg}, 11 \mathrm{U}$ ) and alanine dehydrogenase (AlaDH, $10 \mu \mathrm{L}, 11 \mathrm{U}$ ) were successively added. D- or L- alanine was used as amine donor depending on the $(R)$ or $(S)$-transaminase selectivity, respectively.

The resulting mixture was shaken at $30{ }^{\circ} \mathrm{C}$ and $120 \mathrm{rpm}$ for $24 \mathrm{~h}$. After this time, the reaction was quenched by adding an aqueous $\mathrm{NaOH} 4 \mathrm{M}$ solution $(400 \mu \mathrm{L})$ and extracted with EtOAc $(3 \times 500 \mu \mathrm{L})$. The organic phases were combined and dried over $\mathrm{Na}_{2} \mathrm{SO}_{4}$. The reaction crude was analyzed through GC to determine conversion values, requiring an in situ derivatization for the measurement of the enantiomeric excess.

\section{General procedure for the asymmetric transamination} of ketones 3a-c catalyzed by semipurified ArRmut11TA.

Ketones 3a-c $(0.05 \mathrm{mmol}, 50 \mathrm{mM})$ were suspended in a $100 \mathrm{mM}$ phosphate buffer pH $7(500 \mu \mathrm{L})$ containing PLP (1 mM; final concentration $0.5 \mathrm{mM})$ and 2-propylamine (2 $\mathrm{M}$; final concentration $1 \mathrm{M})$. Then, semipurified ArRmut11-TA $(500 \mu \mathrm{L})$ was added and the mixture was shaken at $45{ }^{\circ} \mathrm{C}$ and $120 \mathrm{rpm}$ for $24 \mathrm{~h}$. The reaction was quenched by adding aqueous an aqueous $\mathrm{NaOH} 4 \mathrm{M}$ solution $(400 \mu \mathrm{L})$, extracted with ethyl EtOAc (3 x 500 $\mu \mathrm{L})$. The organic phases were combined and dried over $\mathrm{Na}_{2} \mathrm{SO}_{4}$. Reaction crude was analyzed through GC to determine conversion values, requiring an in situ derivatization for the measurement of the enantiomeric excesses.

General procedure for the preparative reductive amination of ketones 3a-c employing alanine dehydrogenase as regeneration system.

Scale-up was carried out by linear increasing of the reagent amounts reported before. Thus, lyophilized cells of $E$. coli containing overexpressed transaminases (144 mg) were suspended in a $100 \mathrm{mM}$ phosphate buffer $\mathrm{pH} 7(3.8 \mathrm{~mL})$ and the mixture was stirred at $30^{\circ} \mathrm{C}$ and $120 \mathrm{rpm}$ for 30 min. To the resulting suspension the ketones 3a-c $(0.36$ mmol, $50 \mathrm{mM})$, ammonium formate $(720 \mu \mathrm{L}$ of $1.5 \mathrm{M}$ solution in a $100 \mathrm{mM}$ phosphate buffer $\mathrm{pH} 7$; final concentration $150 \mathrm{mM})$, alanine $(1.8 \mathrm{~mL}$ of $1 \mathrm{M}$ solution in a $100 \mathrm{mM}$ phosphate buffer $\mathrm{pH} 7$; final concentration 250 $\mathrm{mM}), \mathrm{NAD}^{+}(720 \mu \mathrm{L}$ of $10 \mathrm{mM}$ solution in a $100 \mathrm{mM}$ phosphate buffer $\mathrm{pH} 7$; final concentration $1 \mathrm{mM}$ ), PLP $(720 \mu \mathrm{L}$ of $10 \mathrm{mM}$ solution in a $100 \mathrm{mM}$ phosphate buffer $\mathrm{pH} 7$; final concentration $1 \mathrm{mM})$, FDH $(19 \mathrm{mg}, 79 \mathrm{U})$ and alanine dehydrogenase (AlaDH, $72 \mu \mathrm{L}, 79 \mathrm{U})$ were successively added. D- or L- alanine was used as amine donor depending on the $(R)$ or $(S)$-transaminase selectivity, respectively.

The resulting mixture was shaken at $30{ }^{\circ} \mathrm{C}$ and $120 \mathrm{rpm}$ for $24 \mathrm{~h}$. The reaction was quenched by adding an aqueous $\mathrm{NaOH} 4 \mathrm{M}$ solution until $\mathrm{pH}$ around 10 and extracted with EtOAc $(3 \times 10 \mathrm{~mL})$. The organic phases were combined, dried over $\mathrm{Na}_{2} \mathrm{SO}_{4}$, filtered and the solvent removed under reduced pressure. Enantiopure amines $(S)-\mathbf{4 a},(R)-\mathbf{4 a}$ and $(S)-4 c$ were isolated as colourless oils (71-88\% yield). A further purification by column chromatography on silica gel $\left(10 \% \mathrm{MeOH} / \mathrm{CH}_{2} \mathrm{Cl}_{2}\right)$ was performed to isolate enantiopure amine $(S)-\mathbf{4 b}$ as colourless oil (40\% yield). For $(R)-4 a$ in $>99 \%$ ee: $[\alpha]_{\mathrm{D}}{ }^{20}=+36.2\left(c 0.5, \mathrm{CHCl}_{3}\right)$. For $(S)-$ $\mathbf{4 b}$ in $>99 \%$ ee: $[\alpha]_{\mathrm{D}}{ }^{20}=-28.2\left(c 0.5, \mathrm{CHCl}_{3}\right)$. For $(R)-4 \mathbf{c}$ in $>99 \%$ ee: $[\alpha]_{\mathrm{D}}{ }^{20}=+20.0\left(c 0.5, \mathrm{CHCl}_{3}\right)$.

\section{Heat purification protocol for ArRmut11}

Lyophilized $E$. coli cells containing overexpressed enzyme $(2 \mathrm{~g})$ were suspended in a $100 \mathrm{mM}$ phosphate buffer $\mathrm{pH} 7(20 \mathrm{~mL})$ and the suspension was sonicated with the following protocol: $1 \mathrm{~s}$ pulse; $4 \mathrm{~s}$ pause; $2.5 \mathrm{~min}$; $40 \%$ amplitude. The mixture was centrifuged for $20 \mathrm{~min}$ at $18000 \mathrm{rpm}$ and $4^{\circ} \mathrm{C}$ and the supernatant was treated for 30 $\min$ at $50{ }^{\circ} \mathrm{C}$. After this time the suspension was centrifuged again for $20 \mathrm{~min}$ at $18000 \mathrm{rpm}$ and $4{ }^{\circ} \mathrm{C}$ and the supernatant containing the active enzyme was stored at $-18{ }^{\circ} \mathrm{C}$. Protein concentration: $26.7 \mathrm{mg} / \mathrm{mL}$ according to 
Bradford's assay. Activity (determined for the deamination of $\alpha$-methylbenzylamine with pyruvate): $16 \mathrm{U} / \mathrm{mL}$.

\section{Acknowledgements}

Financial support of this work by the Spanish Ministerio de Economía y Competitividad (MINECO, CTQ-2013-44153-P project) and the Asturian Regional Government (FC-15GRUPIN14-002) are gratefully acknowledged. E. B. thanks MINECO for a postdoctoral contract. M.L.-I. and D.G.-M. thank Fundación para el Fomento en Asturias de la Investigación Científica Aplicada y la Tecnología (FICYT), while M. R.-M. thanks the Spanish Ministerio de Ciencia e Innovación (MICINN) for predoctoral fellowships.

\section{References}

[1] a) D. O'Hagan, Chem. Soc. Rev. 2008, 37, 308-319; b) T. Furuya, C. A. Kuttruff, T. Ritter, Curr. Opin. Drug. Discovery Dev. 2008, 11, 803-819; c) F.-L. Qing, F. Zheng, Synlett 2011, 1052-1072; d) C. Hollingworth, V. Governeur, Chem. Commun. 2012, 48, 2929-2942; e) S. K. Ritter, Chem. Eng. News 2012, 90, 10-17; f) X.-F. $\mathrm{Wu}, \mathrm{H}$. Neumann, M. Beller, Chem. Eur. J. 2012, 7, 1744-1754; g) T. Liang, C. N. Neumann, T. Ritter, Angew. Chem. Int. Ed. 2013, 52, 8214-8264; h) H. Egami, M. Sodeoka, Angew. Chem. Int. Ed. 2014, 53, 8294-8308; i) M. C. Walker, M. C. Y. Chang, Chem. Soc. Rev. 2014, 43, 6527-6536; j) A. Koperniku, H. Liu, P. B. Hurley, Eur. J. Org. Chem. 2016, 871-886.

[2] P. Jeschke, Pest. Manag. Sci. 2010, 66, 10-27.

[3] a) S. Purser, P. R. Moore, S. Swallow, V. Gouverneur, Chem. Soc. Rev. 2008, 37, 320-330; b) S. M. Ametamey, M. Honer, P. A. Schubiger, Chem. Rev. 2008, 108, 1501-1516; c) K. L. Kirk, Org. Process Res. Dev. 2008, 12, 305-321; d) W. K. Hagmann, J. Med. Chem. 2008, 51, 4359-4369; e) C. Huang, J. McConathy, Curr. Top. Med. Chem. 2013, 13, 871891; f) J. Wang, M. Sánchez-Roselló, J. L. Aceña, C. del Pozo, A. E. Sorochinsky, S. Fustero, V. A. Soloshonok, H. Liu, Chem. Rev. 2014, 114, 2432-2506; g) E. P. Gillis, K. J. Eastman, M. D. Hill, D. J. Donnelly, N. A: Meanwell, J. Med. Chem. 2015, 58, 8315-8359.

[4] D. Cahard, V. Bizet, Chem. Soc. Rev. 2014, 43, 135147.

[5] a) K. Müller, C. Faeh, F. Diederich, Science 2007, 317, 1881-1886; b) E. A. Ilardi, E. Vitaku, J. T. Njardarson, J. Med. Chem. 2014, 57, 2832-2842.

[6] H.-J. Böhm, D. Banner, S. Bendels, M. Kansy, B. Kuhn, K. Müller, U. Obst-Sander, M. Stahl, ChemBioChem 2004, 5, 637-643.

[7] a) B. E. Smart, J. Fluorine Chem. 2001, 109, 3-11; b) P. Kirsch, Modern fluoroorganic chemistry: synthesis, reactivity, applications, 2nd ed.; Wiley-VCH: Weinheim, Germany, 2013.

[8] J. W. Clader, J. Med. Chem. 2004, 47, 1-9.

[9] a) V. A. Petrov, Fluorinated heterocyclic compounds: Synthesis, chemistry, and applications, Wiley-VCH:
Hoboken, New Jersey, USA, 2009; b) V. M. Muzalevskiy, A. V. Shastin, E. S. Balenkova, G. Haufe, V. G. Nenajdenko, Synthesis 2009, 23, 3905-3929; c) F. Meyer, Chem. Commun. 2016, 52, 3077-3094.

[10] D. O’Hagan, H. Deng, Chem. Rev. 2015, 115, 634649.

[11] See for recent articles: a) A. Hibino, H. Ohtake, Process Biochem. 2013, 48, 838-843; b) J. MangasSánchez, E. Busto, V. Gotor, V. Gotor-Fernández, Org. Lett. 2013, 15, 3872-3875; c) A. S. Rowan, T. S. Moody, R. M. Howard, T. J. Underwood, I. R. Miskelly, Y. He, B. Wang, Tetrahedron Asymmetry 2013, 24, 1369-1381; d) W. Borzęcka, I. Lavandera, V Gotor, Tetrahedron Lett. 2013, 54, 5022-5025; e) R.-J. Chen, G.-W. Zheng, Y. Ni, B.-B. Zeng, J.-H. Xu, Tetrahedron: Asymmetry 2014, 25, 1501-1504; f) S. Kara, D. Spickermann, A. Weckbecker, C. Leggewie, I. W. C. E. Arends, F. Hollmann, ChemCatChem 2014, 6 , 973-976; g) A. Díaz-Rodríguez, J. Iglesias-Fernández, C. Rovira, V. Gotor-Fernández, ChemCatChem 2014, 6, 977-980; h) R. O. Lopes, A. S. de Miranda, B. Reichart, T. Glasnov, C. O. Kappe, R. C. Simon, W. Kroutil, L. S. M. Miranda, I. C. R. Leal, R. O. M. A. de Souza, J. Mol. Catal. B: Enzym. 2014, 104, 101-107; i) C. Rodríguez, W. Borzęcka, J. H. Sattler, W. Kroutil, I. Lavandera, V. Gotor, Org. Biomol. Chem. 2014, 12, 673-681; j) R. O. Lopes, J. B. Ribeiro, A. S. de Miranda, G. V. V. da Silva, L. S. M. Miranda, I. C. R. Leal, R. O. M. A. de Souza, Tetrahedron 204, 70, 3239-3242; k) M. López-Iglesias, E. Busto, V. Gotor, V. Gotor-Fernández, J. Org. Chem. 2015, 80, 38153824 ; 1) H. Li, J. Moncecchi, M. D. Truppo, Org. Process Res. Dev. 2015, 19, 695-700; m) G-C. Xu, H.L. Yu, Y.-P. Shang, J.-H. Xum, RSC Adv. 2015, 5, 22703-22711; n) D. Méndez-Sánchez, J. MangasSánchez, E. Busto, V. Gotor, V. Gotor-Fernández, Adv. Synth. Catal. 2016, 358, 122-131; o) S. S: Ribeiro, S. P. de Vasconcellos, P. L. Ramos, J. B. da Cruz, A. L. M. Porto, Curr. Microw. Chem. 2016, 3, 9-13; p) F. M. Perna, M. A. Ricci, A. Scilimati, M. C. Mena, I. Pisano, L. Palmieri, G. Agrimi, P. Vitale, J. Mol. Catal. B: Enzym. 2016, 124, 29-37; q) K. Wu, L. Chen, H. Fan, Z. Zhao, H. Wang, D. Wei, Tetrahedron Lett. 2016, 57, 899-904.

[12] See for recent articles: a) S. S. Ribeiro, C. Raminelli, A. L. M. Porto, J. Fluorine Chem. 2013, 154, 53-59; b) P. Chun, X. Zhu, J. Mol. Catal. B: Enzym. 2013, 97, 184-188; c) X. Wei, X. Jiang, L. Ye, S. Yuan, Z. Chen, M. Wu, H. Yu, J. Mol. Catal. B: Enzym. 2013, 97, 270277; d) C. Kim, J. Lee, J. Cho, Y. Oh, Y. K. Choi, E. Choi, J. Park, M.-J. Kim, J. Org. Chem. 2013, 78, 2571-2578; e) G. Cheng, B. Xia, Q. Wu, X. Lin, RSC $A d v$. 2013, 3, 9820-9828; f) G.-W. Zheng, X.-Y. Liu, Z.-J. Zhang, P. Tian, G.-Q. Lin, J.-H. Xu, RSC Adv. 2013, 3, 20446-20449; g) S. Kim, Y. K. Choi, J. Hong, J. Park, M.-J. Kim, Tetrahedron Lett. 2013, 54, 1185 1188; h) Q. Jin, G. Jia, Y. Zhang, C. Li, Catal. Sci. Technol. 2014, 4, 464-471; i) D. A. Chaplin, M. E. Fox, S. H. B. Kroll, Chem. Commun. 2014, 50, 5858-5860; j) M. Sakulsombat, P. Vongvilai, O. Ramström, Chem. Eur. J. 2014, 20, 11322-11325; k) J. A. Fernández- 
Salas, S. Manzini, S. P. Nolan, Chem. Eur. J. 2014, 20, 13132-13135; 1) K. P. J. Gustafson, R. Lihammar, O. Verho, K. Engström, J.-E. Bäckvall, J. Org. Chem. 2014, 79, 3747-3751; m) O. V. Kucher, A. O. Kolodiazhnaya, O. B. Smolii, D. V. Prisuazhnyk, K. A. Tolmacheva, O. A. Zaporozhets, Y. S. Moroz, P. K. Mykhailiuk, A. A. Tolmachev, Eur. J. Org. Chem. 2014, 7692-7698; n) E. Fernández-Álvaro, J. Esquivias, M. Pérez-Sánchez, P. Domínguez de María, M. J. Remuiñán-Blanco, J. Mol. Catal. B: Enzym. 2014, 100, 1-6; o) D. Méndez-Sánchez, N. Ríos-Lombardía, S. García-Granda, J. Montejo-Bernardo, A. FernándezGonzález, V. Gotor, V. Gotor-Fernández, Tetrahedron: Asymmetry 2014, 25, 381-386; p) G. Xu, X. Dai, S. Fu, J. Wu, L. Yang, Tetrahedron Lett. 2014, 55, 397-402; q) I. M. Ferreira, R. H. V. Nishimura, A. B. A. Souza, G. C. Clososki, S. A. Yoshioka, A. L. M. Porto, Tetrahedron Lett. 2014, 55, 5062-5065; r) A. Singh, J. Falabella, T. L. LaPorte, A. Goswami, Org. Process Res. Dev. 2015, 19, 819-830; s) G. Xu, S. Lan, S. Fu, J. Wu, L. Yang, Tetrahedron Lett. 2015, 56, 2714-2719.

[13] a) C. K. Savile, J. M. Janey, E. C. Mundorff, J. C. Moore, S. Tam, W. R. Jarvis, J. C. Colbeck, A. Krebber, F. J. Fleitz, J. Brands, P. N. Devine, G. W. Huisman, G. J. Hughes, Science 2010, 329, 305-309: b) M. Truppo, J. M. Janey, B. Grau, K. Morley, S. Pollack, G. Hughes, I. Davies, Catal. Sci. Technol. 2012, 2, 1556-1559; c) M. D. Truppo, H. Strotman, G. Hughes, ChemCatChem 2012, 4, 1071-1074; d) J. Hopwood, M. D. Truppo, N. J. Turner, R. C. Lloyd, Chem. Commun. 2011, 47, 773775; e) M. S. Malik, E.-S. Park, J.-S. Shin, Green Chem. 2012, 14, 2137-2140; f) J. S. Reis, R. C. Simon, W. Kroutil, L. H. Andrade, Tetrahedron: Asymmetry 2013, 24, 1495-1501; g) R. L. Hanson, R. M. Johnston, S. L. Goldberg, W. L. Parker, A. Goswami, Org. Process Res. Dev. 2013, 17, 693-700; h) R. E. Meadows, K. R. Mulholland, M. Schürmann, M. Golden, H. Kierkels, E. Meulenbroeks, D. Mink, O. May, C. Squire, H. Straatman, A. S. Wells, Org. Process Res. Dev. 2013, 17, 1117-1122; i) L. Frodsham, M. Golden, S. Hard, M. N. Kenworthy, D. J. Klauber, K. Leslie, C. Macleod, R. E. Meadows, K. R. Mulholland, J. Reilly, C. Squire, S. Tomasi, D. Watt, A. S. Wells, Org. Process Res. Dev. 2013, 17, 1123-1130; j) E.-S. Park, M. S. Malik, J.-Y. Dong, J.-S. Shin, ChemCatChem 2013, 5, 1734-1738; k) M. Päiviö, L. T. Kanerva, Process Biochem. 2013, 48, 1488-1494; 1) M. Shon, R. Shanmugavel, G. Shin, S. Mathew, S.-H. Lee, H. Yun, Chem. Commun. 2014, 50, 12680-12683; m) C. E. Paul, M. Rodríguez-Mata, E. Busto, I. Lavandera, V. Gotor-Fernández, V. Gotor, S. García-Cerrada, J. Mendiola, Ó. de Frutos, I. Collado, Org. Process Res. Dev. 2014, 18, 788-792; n) N. G. Schmidt, R. C. Simon, W. Kroutil, Adv. Synth. Catal. 2015, 357, 1815-1821; o) A. K. Holzer, K. Hiebler, F. G. Mutti, R. C. Simon, L. Lauterbach, O. Lenz, W. Kroutil, Org. Lett. 2015, 17, 2431-2433; p) A. Cuetos, M. García-Ramos, E.-M. Fischereder, A. Díaz-Rodríguez, G. Grogan, V. Gotor, W. Kroutil, I. Lavandera, Angew. Chem. Int. Ed. 2016, 55, 3144-3147.
[14] T. C. Nugent, Chiral Amine Synthesis: Methods, Developments and Applications, Wiley-VCH, Weinheim, 2010.

[15] a) M. Breuer, K. Ditrich, T. Habicher, B. Hauer, M. Keßeler, R. Stürmer, T. Zelinski, Angew. Chem. Int. Ed. 2004, 43, 788-824; b) J. Duan, P. Li Catal. Sci. Technol. 2014, 4, 311-320; c) B. M. Paz, H. Jiang, K. A. Jørgensen, Chem. Eur. J. 2015, 21, 1846-1853; d) H. Ishikawa, S. Shiomi, Org. Biomol. Chem. 2016, 14, 409-424.

[16] For recent reviews about the biocatalytic synthesis of chiral amines: a) D. Ghislieri, N. J. Turner, Top. Catal. 2014, 57, 284-300; b) M. Fuchs, J. E. Farnberger, W. Kroutil, Eur. J. Org. Chem. 2015, 6965-6982; c) O. Verho, J.-E. Bäckvall, J. Am. Chem. Soc. 2015, 137, 3996-4009; d) G. Grogan, N. J. Turner, Chem. Eur. J. 2016, 22, 1900-1907.

[17] a) U. Hanefeld, Org. Biomol. Chem. 2003, 1, 24052415; b) F. van Rantwijk, R. A. Sheldon, Tetrahedron 2004, 60, 501-519; c) E. Busto, V. Gotor-Fernández, V. Gotor, Chem. Rev. 2011, 111, 3998-4035; d) D. Méndez-Sánchez, M. López-Iglesias, V. GotorFernández, Curr. Org. Chem. 2016, 20, 1186-1203.

[18] a) L. E. Iglesias, V. M. Sánchez, F. Rebolledo, V. Gotor, Tetrahedron: Asymmetry, 1997, 8, 2675-2677; b) O. Torre, E. Busto, V. Gotor-Fernández, V. Gotor, Adv. Synth. Catal. 2007, 349, 1481-1488; c) J. B. Crawford, R. T. Skerlj, G. J. Bridger, J. Org. Chem. 2007, 72, 669-671; d) K. Ditrich, Synthesis 2008, 14, 2283-2287; e) L. K. Thalén, D. Zhao, J.-B. Sortais, J. Paetzold, C. Hoben, J.-E. Bäckvall, Chem. Eur. J. 2009, 15, 3403-3410 f) K. P. J. Gustafson, R. Lihammar, O. Verho, K. Engström, J.-E. Bäckvall, J. Org. Chem. 2014, 79, 3747-3751; g) F. Xu, Q. Wu, X. Chen, X. Lin, Q. Wu, Eur. J. Org. Chem. 2015, 5393-5401.

[19] a) F. Balkenhohl, K. Ditrich, B. Hauer, W. Ladner, J. Prakt. Chem. 1997, 339, 381-384; b) M. Cammenberg, K. Hult, S. Park, ChemBioChem 2006, 7, 1745-1749; c) M. A. J. Veld, K. Hult, A. R. A. Palmans, E. W. Meijer, Eur. J. Org. Chem. 2007, 5416-5421; d) M. RodríguezMata, E. García-Urdiales, V. Gotor-Fernández, V. Gotor, Adv. Synth. Catal. 2010, 352, 395-406; e) M. Paravidino, U. Hanefeld, Green Chem. 2011, 13, 26512657; f) S. Jung, J. Kim, S. Park, $R S C A d v$. 2013, 3, 2590-2594.

[20] a) C.-S. Chen, Y. Fujimoto, G. Girdaukas, C. J. Sih, J. Am. Chem. Soc. 1982, 104, 7294-7299; b) Online tool: K. Faber, W. Kroutil, G. Thallinger, http://biocatalysis.uni-graz.at/enantio/cgi-bin/enantio.pl

[21] a) D. Koszelewski, K. Tauber, K. Faber, W. Kroutil, Trends Biotechnol. 2010, 28, 324-332; b) S. Mathew, H. Yun, ACS Catal. 2012, 2, 993-1001; c) M. S. Malik, E.S. Park, J.-S. Shin, Appl. Microbiol. Biotechnol. 2012 94, 1163-1171; d) R. C. Simon, N. Richter, E. Busto, W. Kroutil, ACS Catal. 2014, 4, 129-143; e) R. C. Simon, E. Busto, E.-M. Fischereder, C. S. Fuchs, D. Pressnitz, N. Richter, W. Kroutil in Science of Synthesis, Biocatalysis in Organic Synthesis (Eds. K. Faber, W.-D. Fessner, N. J. Turner, Georg Thieme 
Verlag), Stuttgart, 2015, pp 383-420; f) E. Busto, R. C. Simon, N. Richter, W. Kroutil in Green Biocatalysis (Ed. R. N. Patel), John Wiley \& Sons, Inc. New Jersey, 2016, pp. 17-57.

[22] B.-Y. Hwang, B.-K. Cho, H. Yun, K. Koteshwar, B.G. Kim, J. Mol. Catal. B: Enzym. 2005, 37, 47-55.

[23] U. Kaulman, K. Smithies, M. E. B. Smith, H. C. Hailes, J. M. Ward, Enzyme Microb. Technol. 2007, 41, 628-637.

[24] S. Pannuri, S. V. Kamat, A. R. M. Garcia, (Cambrex North Brunswick Inc.), PCT Int. Appl. 2006, WO 2006063336 A2 20060615.

[25] a) Y. Yamada, A. Iwasaki, N. Kizaki, K. Matsumoto, Y. Ikenaka, M. Ogura, J. Hasegawa, (Kaneka Corporation), PCT Int. Appl. 1998, WO 9848030 A1 19981029; b) A. Iwasaki, Y. Yamada, N. Kizaki, Y. Ikenaka, J. Hasegawa, Appl. Microbiol. Biotechnol. 2006, 69, 499-505; c) F. G. Mutti, C. S. Fuchs, D. Pressnitz, J. H. Sattler, W. Kroutil, W. Adv. Synth. Catal. 2011, 353, 3227-3233.

[26] C. K. Savile, J. M. Janey, E. M. Mundorff, J. C. Moore, S. Tam, W. R. Jarvis, J. C. Colbeck, A. Krebber, F. J. Fleitz, J. Brands, P. N. Devine, G. W. Huisman, G. J. Georges, Science 2010, 329, 305-309.

[27] H. E. Smith, L. J. Schaad, R. B. Banks, C. J. Wiant, C. F. Jordan, J. Am. Chem. Soc. 1973, 95, 811-818.
[28] R. J. Kazlauskas, A. N. E. Weissfloch, A. T. Rappaport, L. A. Cuccia, J. Org. Chem. 1991, 56, 2656-2665.

[29] M. López-Iglesias, D. González-Martínez, V. Gotor, E. Busto, W. Kroutil, V. Gotor-Fernández, ACS Catal. 2016, 6, 4003-4009.

[30] a) M. S. Humble, K. E. Cassimjee, M. Håkansson, Y. R. Kimbung, B. Walse, V. Abedi, H.-J. Federsel, P. Berglund, D. T. Logan, FEBS J. 2012, 279, 779-792; b) K. E. Cassimjee, B. Manta, F. Himo, Org. Biomol. Chem. 2015, 13, 8453-8464.

[31] G. M. Morris, R. Huey, W. Lindstrom, M. F. Sanner, R. K. Belew, D. S. Goodsell, A. J. Olson, J. Comput. Chem. 2009, 16, 2785-2791.

[32] a) E. R. Johnson, S. Keinan, P. Mori-Sánchez, J. Contreras-García, A. J. Cohen, W. Yang, J. Am. Chem. Soc. 2010, 132, 6498-6506; b) J. Contreras-García, E. R. Johnson, S. Keinan, R. Chaudret, J-P. Piquemal, D. N. Beratan, W. Yang. J. Chem. Theory Comput. 2011, 7, 625-632; c) R. Soria-Martínez, R. Mendoza-Merono, S. García-Granda, J. Mol. Struct. 2016, 1105, 322-331. 


\section{FULL PAPER}

Asymmetric biocatalytic synthesis of fluorinated pyridines through transesterification or transamination. Computational insights into the reactivity of transaminases.

Adv. Synth. Catal. Year, Volume, Page - Page

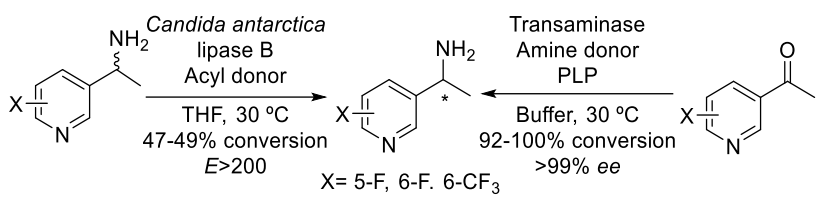

María López-Iglesias, Daniel González-Martínez, María Rodríguez-Mata, Vicente Gotor, Eduardo Busto,* Wolfgang Kroutil* and Vicente GotorFernández* 